(2) norden 



\section{Aksepterte årsaker til sykefravær}

Holdninger i de fem nordiske landene

Opinion, Norge

TemaNord 2007:594 


\section{Aksepterte årsaker til sykefravær}

TemaNord 2007:594

Holdninger i de fem nordiske landene

(C) Nordisk Ministerråd, København 2007

ISBN 978-92-893-1594-4

Trykk: Ekspressen Tryk \& Kopicenter

Opplag: 0

Trykt på miljøvennlig papir som oppfyller kravene i den nordiske miljøsvanemerkeordning.

Publikasjonen kan bestilles på www.norden.org/order. Flere publikasjoner på

www.norden.org/publikationer

Printed in Denmark

Nordisk Ministerråd

Store Strandstræde 18

1255 Copenhagen $\mathrm{K}$

Telefon (+45) 33960200

Fax (+45) 33960202

www.norden.org

\section{Nordisk Råd}

Store Strandstræde 18

1255 Copenhagen $\mathrm{K}$

Telefon (+45) 33960400

Fax $(+45) 33111870$

\section{Det nordiske samarbeidet}

Det nordiske samarbeid er en av verdens mest omfattende regionale samarbeidsformer. Samarbeidet omfatter Danmark, Finland, Island, Norge og Sverige, samt de selvstyrende områdene Færøyene, Grønland og Åland.

Det nordiske samarbeid er både politisk, økonomisk og kulturelt forankret, og er en viktig medspiller i det europeiske og internasjonale samarbeid. Det nordiske fellesskap arbeider for et sterkt Norden i et sterkt Europa.

Det nordiske samarbeid ønsker å styrke nordiske og regionale interesser og verdier i en global omverden. Felles verdier landene imellom er med til å styrke Nordens posisjon som en av verdens mest innovative og konkurransekraftige regioner. 


\section{Innholdsfortegnelse}

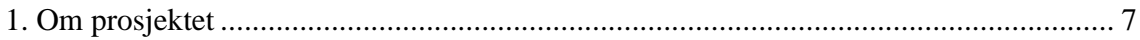

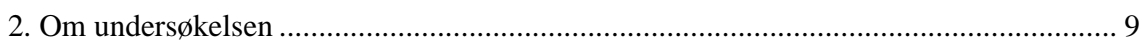

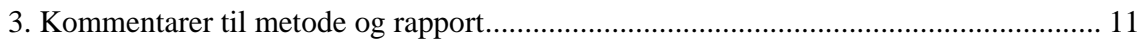

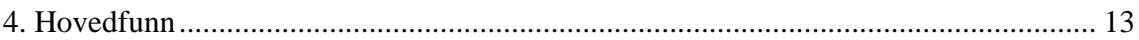

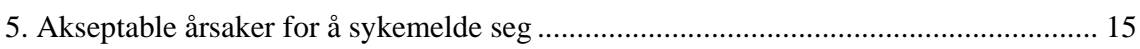

5.1. Akseptable årsaker for å sykemelde seg - ”Er forkjølet med litt feber”.............. 16

5.2. Akseptable årsaker for å sykemelde seg - ”Har nære familiemedlemmer som

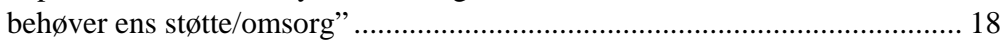

5.3. Akseptable årsaker for å sykemelde seg - "Blir mobbet på arbeidsplassen”....... 19

5.4. Akseptable årsaker for å sykemelde seg - ”Har vanskeligheter i forbindelse med samlivsbrudd"

5.5. Akseptable årsaker for å sykemelde seg - ”Føler ubehag pga. stress på arbeidet”

5.6. Akseptable årsaker for å sykemelde seg - ”Har problemer med å komme seg på jobb pga. kortvarig manglende tilbud i barnehage, skole eller offentlig transport” 3

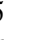
8 



\section{Om prosjektet}

Kontaktgruppe for sykefravær i Norden ønsket å få gjennomført en kartlegging av holdninger til sykefravær i alle de nordiske land. Målet med undersøkelsen var å avdekke holdninger i befolkningen i de nordiske landene når det gjelder hva de vurderer er godtatte årsaker til sykefravær.

Alle de nordiske land har offentlige ordninger som sikrer inntekt til personer som blir syke. Mellom de nordiske landene er det forskjeller i hvor sjenerøs ordningene er. Ytterpunktene er Norge med 100 pst. dekning av bortfall av inntektsevne ved sykefravær og Island som har en mer forsikringsbasert ordning. På denne bakgrunn er det prosjektets formål å identifisere om dette også avspeiles i holdninger til sykefravær i de nordiske land. Konkret forventes det at en mer sjenerøs sykelønnsordning vil påvirke holdninger i retning av at det er akseptert melde seg syk i flere situasjoner. 



\section{Om undersøkelsen}

Undersøkelsen er gjennomført som telefonundersøkelser i de fem nordiske landene; Norge, Sverige, Island, Danmark og Finland.

Ansvarlig for selve datainnsamlingen i de ulike landene har vært:

I Norge: Norstat Norge

I Sverige: Norstat Sverige

I Danmark og på Island: Norstat Danmark

I Finland: STP OY

Det er gjennomført 1000 intervjuer i hvert land med et tilfeldig utvalg av befolkningen mellom 18 og 65 år. Kravet for å kunne delta i undersøkelsen var at man måtte arbeide åtte timer gjennomsnittlig per uke eller mer. Intervjuene er gjennomført i perioden uke 33 - uke 362007.

Kontaktgruppen for sykefravær i Norden har selv utarbeidet selve problemstillingene i spørreskjemaet (som hvilke årsaker til sykemelding og hvilke påstander som skulle testes ut). Opinion har utviklet selve spørreskjemaet på bakgrunn av dette arbeidet.

Opinion AS i Oslo har vært ansvarlig for gjennomføringen av undersøkelsen ved seniorkonsulent Thor Erik Johansen (tej@opinion.no) og konsulent Anette Heier (ah@opinion.no).

Arbeids- og inkluderingsdepartementet i Norge ved Bent-Ole Grooss har vært ansvarlig for gjennomføringen av prosjektet fra Nordisk Ministerråds side 



\section{Kommentarer til metode og rapport}

Spørreskjema inneholdt foruten spørsmål om bakgrunnsinformasjon tre spørsmålsmoduler.

Først ble alle respondentene spurt spørsmålet ”Det er akseptabelt å sykemelde seg når man [...]” i forhold til ni potensielle årsaker til sykemelding. Respondentene svarte langs en skala fra 1 til 10 der 1 betyr "Aldri akseptabelt" og 10 betyr "Alltid akseptabelt".

For seks av de potensielle årsakene til sykemelding ble de respondentene som svarte andre alternativer enn "Aldri akseptabelt" fulgt opp og spurt hvor lang sykemelding som kan godtas i det enkelte tilfellet. Noen respondenter svarte nå at sykemelding aldri kan godtas selv om de ikke hadde svart "Aldri akseptabelt” i det første spørsmålet. Disse respondentene har i etterkant blitt kodet om til "Aldri akseptabelt” i det første spørsmålet.

Deretter skulle respondentene ta stilling til tre påstander om langtids sykemelding.

Spørreskjema ligger som vedlegg bak i rapporten.

Noen av resultatene i rapporten presenteres som svarfordelinger på følgende måte:

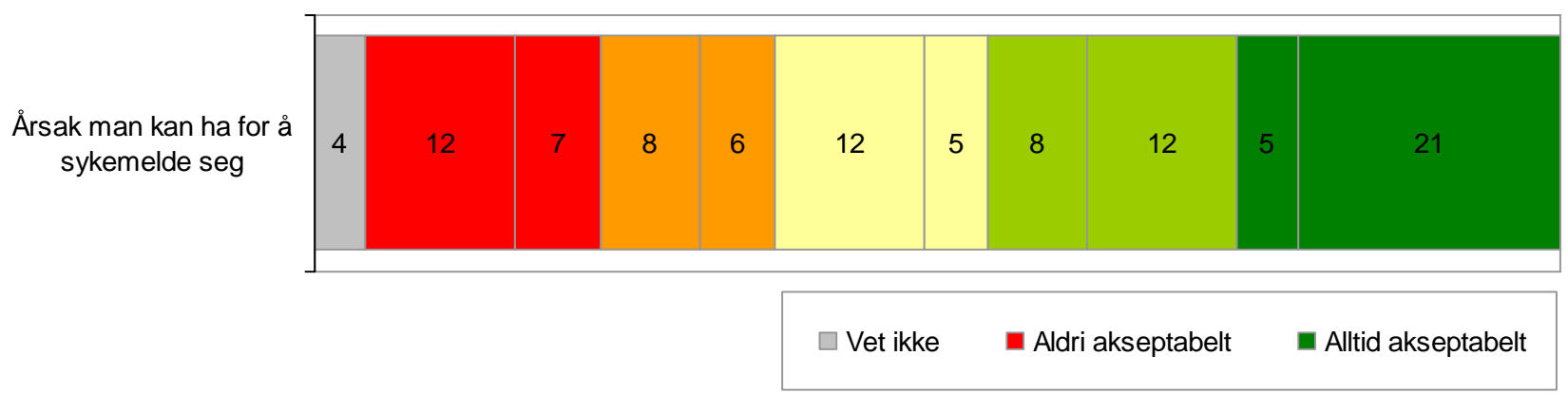

I denne rapporten presenteres både resultater for Norden under ett og resultater for de enkelte landene. De nordiske resultatene fremkommer ved at resultatene for de enkelte landene er vektet i henhold til befolkningsstørrelsen.

Det røde feltet helt til venstre viser andelen som har svart "Aldri akseptabelt” (12\%), mens det mørke grønne feltet helt til høyre viser andelen som har svart "Alltid akseptabelt" (21\%). Feltene imellom viser resten av svarfordelingen, dvs. de som svarte alternativene 2-9.

I tillegg til denne rapporten er det utarbeidet separate rapporter for de ulike landene der resultater presenteres grafisk. For detaljer om resul- 
tatene for det enkelte land henvises det derfor til disse rapportene. Nedbrytningene mot bakgrunnsvariable i denne rapporten gjelder Norden som helhet.

Denne rapporten og de separate landsrapportene er i hovedsak deskriptive fremstillinger av resultatene fra undersøkelsen. Data fra undersøkelsen vil også bli analysert nærmere av en forskningsinstitusjon for å finne om det er noen sammenheng mellom sykefraværsordningen og holdninger til det å melde seg syk i de enkelte nordiske land. Forskningsinstitusjonen vil utarbeide en egen rapport om dette. 


\section{Hovedfunn}

Det er klare forskjeller i holdninger til hvilke årsaker som er akseptable for sykemelding.

I Norden sett under ett er det å være forkjølet med litt feber den mest akseptable årsaken til sykemelding. 21 \% aksepterer alltid denne årsaken, mens $12 \%$ aldri aksepterer denne årsaken. Andre årsaker som mange aksepterer er det å ha nære familiemedlemmer som behøver ens støtte/omsorg og det å bli mobbet på arbeidsplassen.

Den årsaken færrest synes er en akseptabel årsak til sykemelding er det å føle seg dårlig etter å ha drukket for mye alkohol kvelden før. Kun 1 \% aksepterer alltid denne årsaken, mens $80 \%$ aldri aksepterer denne årsaken. Andre årsaker som få aksepterer er det å ha fått for lite søvn og det å være misfornøyd med forhold på arbeidsplassen.

Hvis man ser alle årsakene til sykemelding under ett så er det små forskjeller mellom Norge, Sverige, Island og Finland. Det varierer imidlertid noe mellom landene når det gjelder hvilke årsaker som i høyest grad aksepteres. Danmark utpeker seg imidlertid som det landet der man i gjennomsnitt i høyest grad aksepterer de ulike årsakene til sykemelding. I vurdering av årsakene kan vi se forskjeller mellom menn og kvinner. Noen årsaker aksepteres mer av kvinner andre aksepteres mer av menn. De fleste årsakene aksepteres i større grad av unge enn av eldre arbeidstagere.

Utdanning har ulik betydning for aksept av de ulike årsakene.

De fleste årsakene aksepteres i større grad av de som arbeider i offentlig sektor enn av de som arbeider i privat sektor.

Det er en tendens til at de som arbeider i større bedrifter i større grad aksepterer de ulike årsakene enn de som arbeider i mindre bedrifter. De fleste årsakene aksepteres i mindre grad av de som arbeider mange timer i uken enn av de som arbeider få timer i uken.

Det er også klare forskjeller mellom hvor lenge de ulike årsaken til sykemelding aksepteres.

I Norden sett under ett er den årsaken man godtar lengst sykemelding for det å bli mobbet på arbeidsplassen. I gjennomsnitt godtar man 21 dagers sykemelding knyttet til denne årsaken. Den årsaken man godtar nest lengst sykemelding for er det å føle ubehag pga. stress på arbeidet (19 dager).

Den årsaken man godtar kortest sykemelding for er det å ha fått for lite søvn. I gjennomsnitt godtar man 4 dagers sykemelding knyttet til denne årsaken.

Hvis vi ser på de seks årsakene til sykemelding under ett, og regner ut et gjennomsnitt av antall dager sykemelding som kan godtas ser vi at 
arbeidstagere i Danmark og i Norge er de som i gjennomsnitt godtar flest sykemeldingsdager, uavhengig av årsak. 17 dager i Danmark og 16 dager i Norge. Arbeidstagere i Finland og på Island er de som i gjennomsnitt godtar færrest sykemeldingsdager, uavhengig av årsak. Syv dager i Finland og seks dager på Island.

For de fleste årsakene godtar kvinner flere sykemeldingsdager enn menn. Når det gjelder alder er det en tendens til at de mellom 30 og 49 år aksepterer flest sykemeldingsdager.

De som arbeider i offentlig sektor aksepterer flere sykemeldingsdager enn de som arbeider i privat sektor

De som arbeider mange timer i uken aksepterer færre sykemeldingsdager enn de som arbeider færre timer i uken.

Norden sett under ett så er 36 \% av arbeidstagerne enige i påstanden ”Jeg synes det er mer akseptabelt å være sykemeldt hvis det er ansatt vikar i stillingen”.

o Arbeidstagerne på Island og i Finland er de som i høyest grad sier de er enige i påstanden.

o De yngste og kvinnene er i størst grad enige i påstanden.

o De som arbeider i offentlig sektor er i høyere grad enn de som arbeider i privat sektor enige i påstanden.

o Andelen som er enige i påstanden synker med størrelsen på bedriften arbeidstagerne arbeider $\mathrm{i}$.

Norden sett under ett så er 19 \% av arbeidstagerne enige i påstanden ”Jeg synes det er mer akseptabelt å være sykemeldt når det offentlige dekker utgiftene til sykelønn”.

o Arbeidstagerne i Finland er de som i høyest grad sier de er enige i påstanden.

o De yngste og kvinnene er i størst grad enige i påstanden.

o Andelen som er enige i påstanden synker med størrelsen på bedriften arbeidstagerne arbeider $\mathrm{i}$.

Norden sett under ett så er 81 \% av arbeidstagerne enige i påstanden ”Jeg kunne tenke meg å arbeide helt eller delvis i en sykdomsperiode hvis arbeidsgiver tilrettelegger for meg”.

o Arbeidstagerne i Norge og Sverige er de som i høyest grad sier de er enige i påstanden.

o De som er 50-65 år gamle er i mindre grad enige i påstanden enn de som er yngre.

o De som arbeider i offentlig sektor er i noe høyere grad enige i påstanden enn de som arbeider i privat sektor. 


\section{Akseptable årsaker for å sykemelde seg}

Spørsmål: Det er akseptabelt å sykemelde seg når man... $(n=5000)$

Har nære familiemedlemmer som behøver ens støtte/omsorg

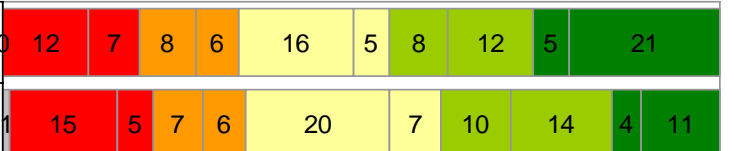

Blir mobbet på arbeidsplassen

Har vanskeligheter i forbindelse med samlivsbrudd

Føler ubehag pga. stress på arbeidet

Har problemer med å komme seg på jobb pga. kortvarig manglende tilbud i barnehage, skole eller offentlig transport

Er misfornøyd med forhold på arbeidsplassen

Har fått for lite søvn

$$
12
$$
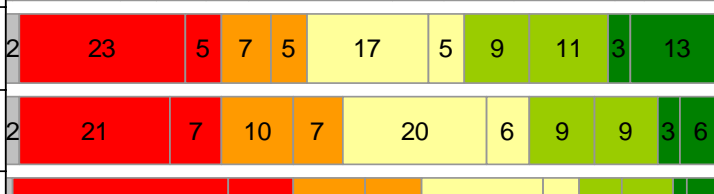

10
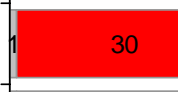

9
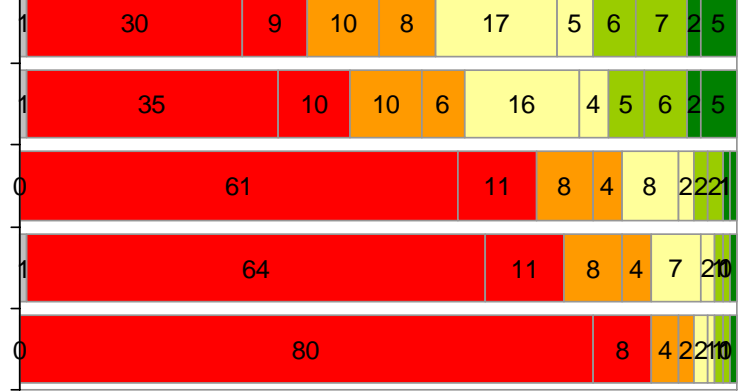

Føler seg dårlig etter å ha drukket mye alkohol kvelden før

- Alltid akseptabelt

Ser man Norden under ett så er det å være forkjølet med litt feber den mest akseptable årsaken til sykemelding. $21 \%$ aksepterer alltid denne årsaken, mens kun $12 \%$ aldri aksepterer denne årsaken (index 551). Andre årsaker som mange aksepterer er det å ha nære familiemedlemmer som behøver ens støtte/omsorg (index 50), det å bli mobbet på arbeidsplassen (index 45) og det å ha problemer i forbindelse med samlivsbrudd (index 40).

Den årsaken færrest synes er en akseptabel årsak til sykemelding er det å føle seg dårlig etter å ha drukket mye alkohol kvelden før. Kun $1 \%$ aksepterer alltid denne årsaken, mens 80 \% aldri aksepterer denne årsaken (index 6). Andre årsaker som få aksepterer er det å ha fått for lite

\footnotetext{
${ }^{1}$ Index er gjennomsnittscoren på det enkelte spørsmålet standardisert på en skala fra 0 til 100 . Hvis alle hadde svart "aldri akseptabelt” på et spørsmål ville index bli 0. Hvis alle hadde svart "alltid akseptabelt” på et spørsmål ville index blitt 100. Dvs. jo større index, jo mer akseptabelt som årsak for sykemelding. Index er en hensiktsmessig måte å sammenligne resultater på mellom ulike undergrupper og mellom land da den tar hensyn til hele svarfordelingen.
} 
søvn (index 11) og det å være misfornøyd med forhold på arbeidsplassen (index 14).

Det er relativt små forskjeller mellom de ulike landene når det gjelder rangeringen av akseptable årsaker til sykemelding. Vi kan imidlertid se at det å føle ubehag pga. stress i arbeidet i Danmark er den mest akseptable årsaken. Denne årsaken er rangert som nummer fem eller seks (av ni årsaker) i de andre landene.

Hvis vi ser på alle årsakene til sykemelding under ett som oppnår man en gjennomsnittlig index for Norden på 31. Gjennomsnittlig index for Island, Finland, Sverige og Norge varierer mellom 28 og 31, mens Danmark skiller seg ut som det landet der det gjennomsnittlig er mest akseptabelt å sykemelde seg med en index på 36.

\subsection{Akseptable årsaker for å sykemelde seg -’Er forkjølet med litt feber”}

Den mest akseptable årsaken for å sykemelde seg var det å være forkjølet med litt feber. La oss se hvordan denne årsaken aksepteres i de ulike landene.

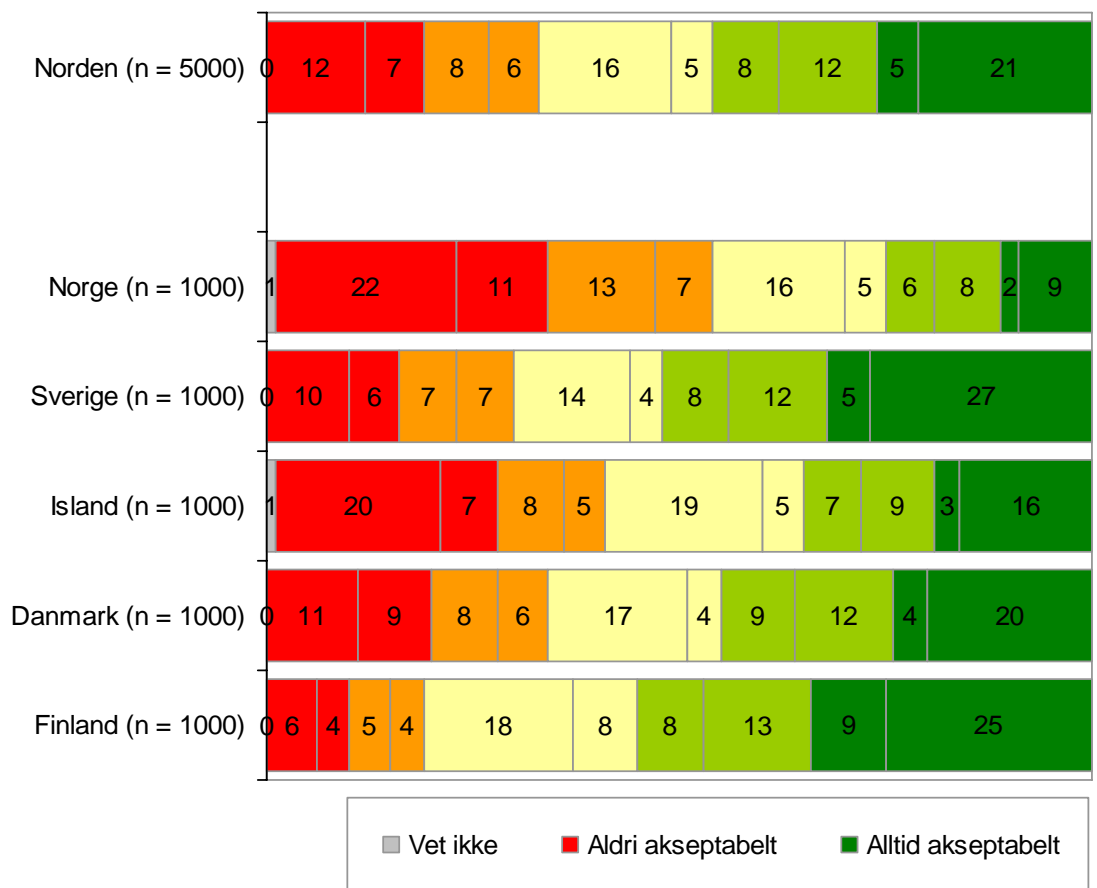

Som vi ser av figuren ovenfor er det en del forskjeller fra land når det gjelder hvor akseptabelt det å være forkjølet med litt feber er som årsak til sykemelding. Denne årsaken er mest akseptert i Finland og Sverige. I Finland synes $25 \%$ at dette alltid er en akseptabel årsak til sykemelding, 
mens $6 \%$ synes årsaken aldri kan aksepteres (index 65). I Sverige synes $27 \%$ at dette alltid er en akseptabel årsak til sykemelding, mens $10 \%$ synes årsaken aldri er akseptabel (index 59). Nordmenn er de som i minst grad aksepterer det å være forkjølet med litt feber som årsak til sykemelding. $9 \%$ av nordmenn synes alltid dette er en akseptabel årsak til sykemelding, mens $22 \%$ synes årsaken aldri er akseptabel (index 38). Forskjellene mellom landene er altså ganske markerte.

Ser man på Norden under ett så aksepterer kvinner det å være forkjølet med litt feber i noe høyere grad som årsak til sykemelding enn det menn gjør (index 57 mot 52).

Yngre i Norden aksepter denne årsaken i noe høyere grad enn eldre. Det oppnås en index på 58 blant de som er 39 år eller yngre, mens det oppnås en index på 52 i vår eldste aldersgruppe; 50 - 65 år.

Det å være forkjølet med litt feber aksepteres i høyere grad som en årsak til sykemelding ved økende utdanning i Norden sett under ett. Det oppnås en index på 46 blant de som har lavest utdanning, mens det oppnås en index på 59 blant de som har høyest utdanning.

De som arbeider i offentlig sektor aksepterer denne årsaken i høyere grad enn de som arbeider i privat sektor, Norden sett under ett. Det oppnås en index på 58 blant de som arbeider i offentlig sektor, mens det oppnås en index på 53 blant de som arbeider i privat sektor. Lavest aksept er det blant selvstendig næringsdrivende (index 46).

I Norden sett under ett aksepteres det å være forkjølet med litt feber i høyere grad som en årsak til sykemelding ved økende størrelse på bedriften arbeidstagerne jobber i (økende antall ansatte). Det oppnås en index på 50 blant de som arbeider i bedrifter med under 15 ansatte, mens det oppnås en index på 58 blant de som arbeider i bedrifter med 200 ansatte eller mer.

Det er kun mindre forskjeller når det gjelder å akseptere denne årsaken avhengig av hvor mange timer man arbeider i uken, Norden sett under ett. Vi ser imidlertid en tendens til at de som arbeider mange timer i uken i mindre grad aksepterer denne årsaken enn de som arbeider færre timer i uken.

Når man ser på aksepten blant ulike yrkesgrupper i Norden under ett, finner vi at aksepten for det å være forkjølet med litt feber som en årsak til sykemelding er lavest blant arbeidstagere med følgende yrker: Håndverksyrker (index 44), jordbruk, skogbruk, fiske (index 46), transport (index 47) og ledere (index 51). Den er høyest blant følgende yrker: Ingeniører, IT, telekommunikasjon (index 59) samt kontorarbeid, presse/media/PR, helse/pleie/omsorg (index 58). 


\subsection{Akseptable årsaker for å sykemelde seg - ”Har nære familiemedlemmer som behøver ens støtte/omsorg”}

Den nest mest akseptable årsaken for å sykemelde seg var det å ha nære familiemedlemmer som behøver ens støtte/omsorg. Nedenfor vises hvordan denne årsaken aksepteres i de ulike landene.

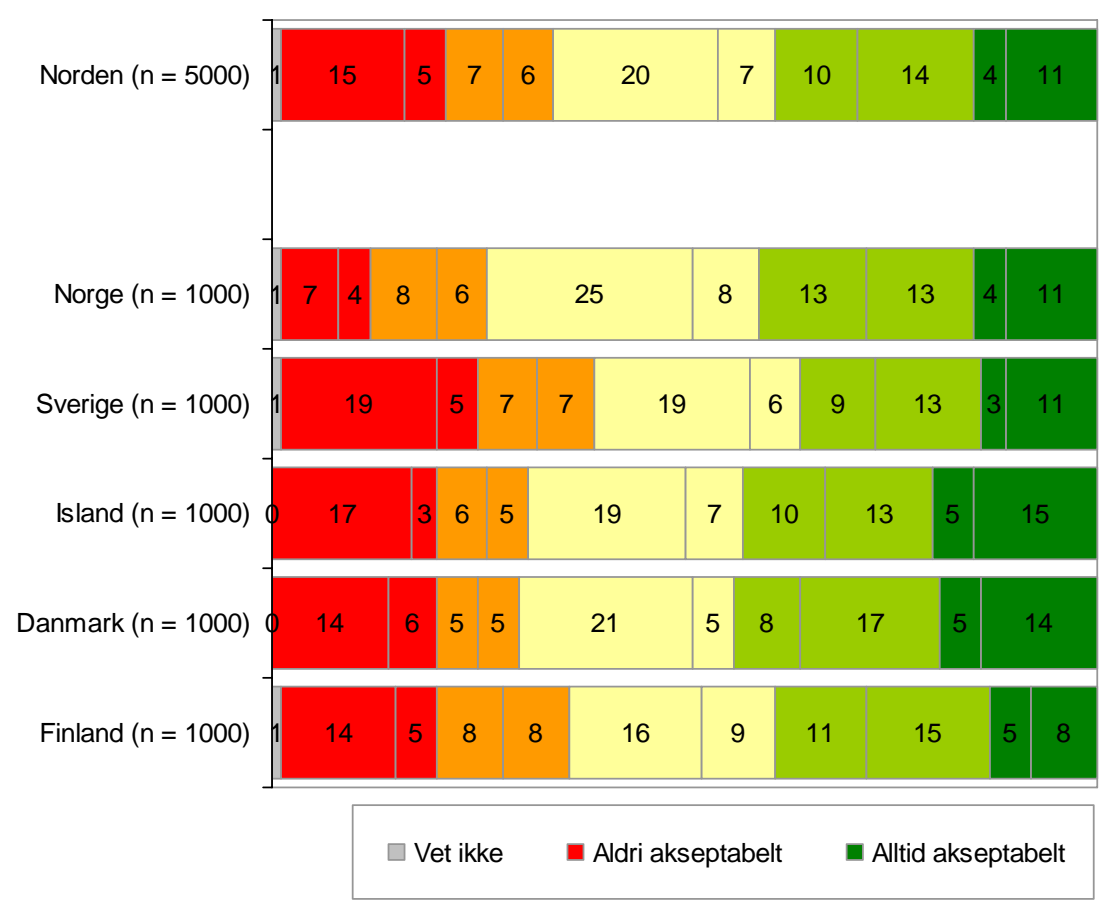

Som vi ser er det en relativt små forskjeller fra land når det gjelder hvor akseptabelt det å ha nære familiemedlemmer som behøver ens pleie/omsorg er som årsak til sykemelding. Denne årsaken er mest akseptert i Danmark, i Norge og på Island. I Danmark synes $14 \%$ at dette alltid er en akseptabel årsak til sykemelding, mens samme andel, $14 \%$ synes årsaken aldri kan aksepteres (index 53). I Norge synes $11 \%$ at dette alltid er en akseptabel årsak til sykemelding, mens 7 \% synes årsaken aldri er akseptabel (index 53). Svensker er de som i minst grad aksepterer det å ha nære familiemedlemmer som behøver ens pleie/omsorg som årsak til sykemelding. $11 \%$ av svensker synes alltid dette er en akseptabel årsak til sykemelding, mens $19 \%$ synes årsaken aldri er akseptabel.

Ser man på Norden under ett så aksepterer menn det å ha nære familiemedlemmer som behøver ens omsorg i noe høyere grad som årsak til sykemelding enn det kvinner gjør (index 52 mot 48).

Det å ha nære familiemedlemmer som behøver ens omsorg aksepteres i mindre grad som en årsak til sykemelding ved økende alder på arbeidstagerne i Norden sett under ett. Det oppnås en index på 55 blant de som 
er under 30 år gamle, mens det oppnås en index på 46 blant de som er i aldersgruppen 50 - 65 år.

Når det gjelder utdanning skiller de med høyest utdanning seg ut som de som i minst grad aksepter det å ha nære familiemedlemmer som behøver ens omsorg som en årsak til sykemelding (index 46).

Det er ingen forskjell mellom de som arbeider i offentlig sektor, de som arbeider i privat sektor og de som arbeider som selvstendig næringsdrivende når det gjelder å akseptere denne årsaken som årsak for sykemelding, Norden sett under ett.

Det er kun små forskjeller mellom de som arbeider i bedrifter med få ansatte og de som arbeider i større bedrifter når det gjelder å akseptere denne årsaken som årsak for sykemelding, Norden sett under ett.

Det er kun små forskjeller mellom de som arbeider få timer i uken og de som arbeider flere timer i uken når det gjelder å akseptere denne årsaken som årsak for sykemelding, Norden sett under ett.

Når man ser på aksepten blant ulike yrkesgrupper i Norden under ett, finner vi at aksepten for det å ha nære familiemedlemmer som behøver ens omsorg som en årsak til sykemelding er lavest blant arbeidstagere med følgende yrker: Kontorarbeid (index 47) og helse/pleie/omsorg (index 46). Den er høyest blant de som arbeider innen håndverksyrker (index 54). Men forskjellene er som vi ser ikke store mellom ulike yrkesgrupper.

\subsection{Akseptable årsaker for å sykemelde seg - "Blir mobbet på arbeidsplassen”}

Den tredje mest akseptable årsaken for å sykemelde seg var det å bli mobbet på arbeidsplassen. Figuren nedenfor vises hvordan denne årsaken aksepteres i de ulike landene. 


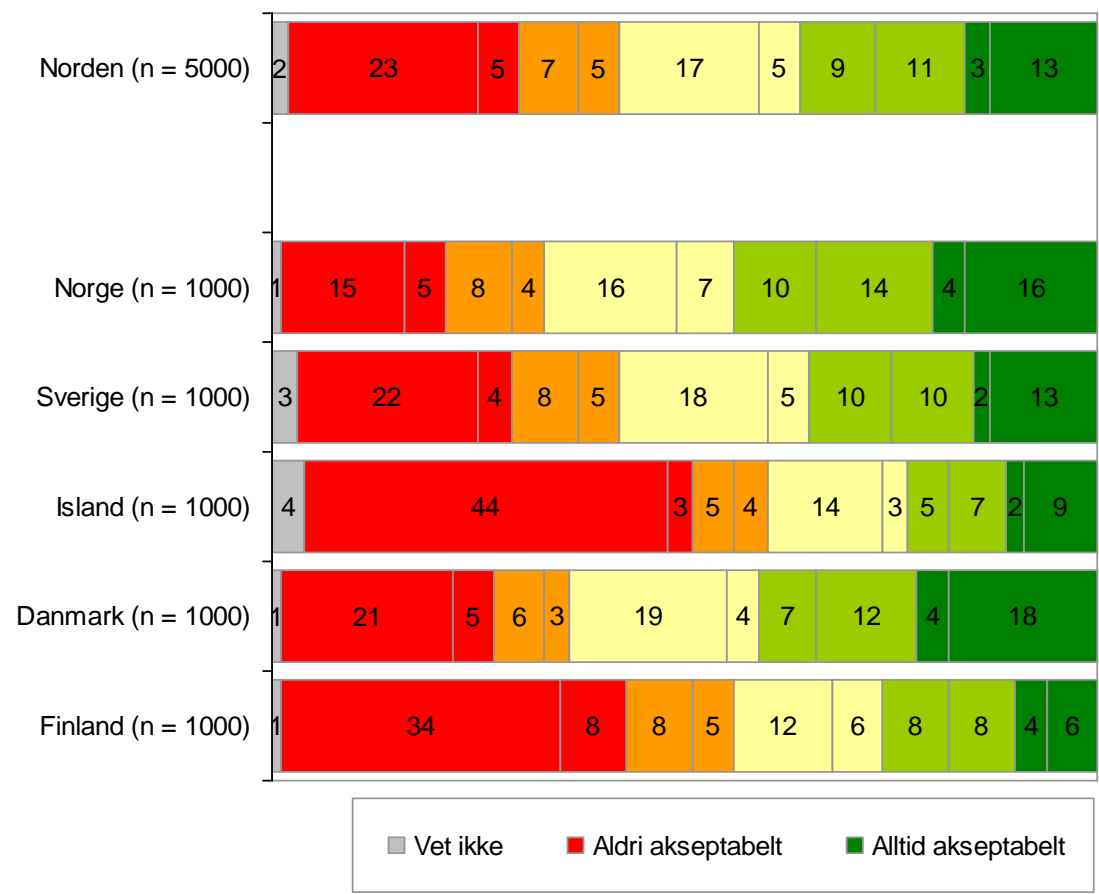

Som vi ser av figuren er det en del forskjeller fra land når det gjelder hvor akseptabelt det å bli mobbet på arbeidsplassen er som årsak til sykemelding. Denne årsaken er mest akseptert i Norge og Danmark. I Norge synes $16 \%$ at dette alltid er en akseptabel årsak til sykemelding, mens $15 \%$ synes årsaken aldri kan aksepteres (index 52). I Danmark synes $18 \%$ at dette alltid er en akseptabel årsak til sykemelding, mens $21 \%$ synes årsaken aldri er akseptabel (index 50). Islendinger og finner er de som i minst grad aksepterer det å bli mobbet på arbeidsplassen som årsak til sykemelding. $9 \%$ av islendingene synes alltid dette er en akseptabel årsak til sykemelding, mens $44 \%$ synes årsaken aldri er akseptabel (index 32). 6 $\%$ av finnene synes alltid dette er en akseptabel årsak til sykemelding, mens $34 \%$ synes årsaken aldri er akseptabel (index 34). Forskjellene er altså ganske markerte.

Ser man på Norden under ett så aksepterer kvinner det å bli mobbet på arbeidsplassen i noe høyere grad som årsak til sykemelding enn det menn gjør (index 47 mot 43).

Når det gjelder alder skiller de som er 50 år eller eldre seg ut som de som i minst grad aksepter det å bli mobbet på arbeidsplassen som en årsak til sykemelding (index 40). Det er ingen forskjeller blant de andre aldersgruppene.

Det er kun små forskjeller mellom utdanningsgrupper når det gjelder å akseptere denne årsaken som årsak for sykemelding, Norden sett under ett.

De som arbeider i offentlig sektor aksepterer denne årsaken i noe høyere grad enn de som arbeider i privat sektor, Norden sett under ett. Det oppnås en index på 47 blant de som arbeider i offentlig sektor, mens det 
oppnås en index på 44 blant de som arbeider i privat sektor. Lavest aksept er det blant selvstendig næringsdrivende (index 39).

Det er kun små forskjeller mellom de som arbeider i bedrifter med få ansatte og de som arbeider i større bedrifter når det gjelder å akseptere denne årsaken som årsak for sykemelding, Norden sett under ett, men en tendens til økt aksept ved økende bedriftsstørrelse.

Det å bli mobbet på arbeidsplassen aksepteres i lavere grad som en årsak til sykemelding ved økende antall timer man arbeider, Norden sett under ett. Det oppnås en index på 50 blant de som arbeider 8 - 31 timer i uken, mens det oppnås en index på 43 blant de som arbeider 40 timer eller mer i uken.

Når man ser på aksepten blant ulike yrkesgrupper i Norden under ett, finner vi at aksepten for det å bli mobbet på arbeidsplassen som en årsak til sykemelding er lavest blant arbeidstagere med følgende yrker: Andre serviceyrker, herunder reiseliv (index 40), industriarbeid (index 40) og ledere (index 41). Den er høyest blant de som arbeider innen presse, media, PR (index 53), megler/konsulent/rådgiver etc. (index 48) og helse/pleie/omsorg (index 47). 


\subsection{Akseptable årsaker for å sykemelde seg - ”Har vanskeligheter i forbindelse med samlivsbrudd"}

Neste årsak til sykemelding vi skal ta for oss er det å ha vanskeligheter i forbindelse med samlivsbrudd. Figuren nedenfor vises hvordan denne årsaken aksepteres i de ulike landene.

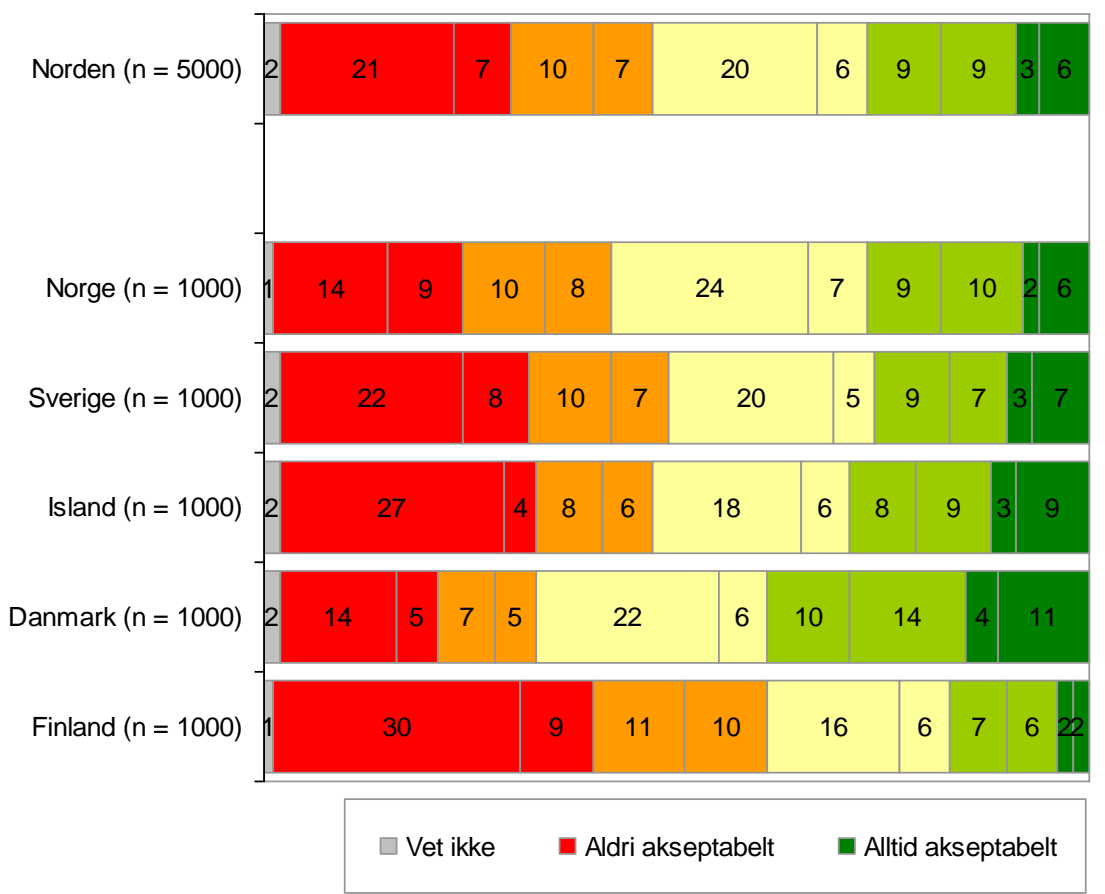

Også her ser vi en del forskjeller fra land når det gjelder hvor akseptabelt det å ha vanskeligheter i forbindelse med samlivsbrudd er som årsak til sykemelding. Denne årsaken er mest akseptert i Danmark. I Danmark synes $11 \%$ at dette alltid er en akseptabel årsak til sykemelding, mens 14 $\%$ synes årsaken aldri kan aksepteres (index 50). Finner er de som i minst grad aksepterer det å ha vanskeligheter i forbindelse med samlivsbrudd som årsak til sykemelding. $2 \%$ av finnene synes alltid dette er en akseptabel årsak til sykemelding, mens 30 \% synes årsaken aldri er akseptabel (index 30).

Kvinner aksepterer det å ha vanskeligheter i forbindelse med samlivsbrudd som årsak for sykemelding i høyere grad enn det menn gjør. Det oppnås en index på 41 blant kvinner og 39 blant menn.

Det er en nedgang i andelen som aksepterer denne årsaken som årsak for sykemelding ved økende alder. Det oppnås en index på 44 blant de som er mellom 18 år og 29 år gamle, mens det oppnås en index på 36 blant de som er mellom 50 år og 66 år gamle.

De som har lavest utdanning aksepterer det å ha vanskeligheter i forbindelse med samlivsbrudd i minst grad som årsak for sykemelding, Nor- 
den sett under ett. Denne utdanningsgruppen skiller seg fra alle med høyere utdanning og det oppnås en index på 36.

De som arbeider i offentlig sektor aksepterer denne årsaken i noe høyere grad enn de som arbeider i privat sektor, Norden sett under ett. Det oppnås en index på 42 blant de som arbeider i offentlig sektor, mens det oppnås en index på 39 blant de som arbeider i privat sektor. Lavest aksept er det blant selvstendig næringsdrivende (index 34).

Det er kun små forskjeller mellom de som arbeider i bedrifter med få ansatte og de som arbeider i større bedrifter når det gjelder å akseptere denne årsaken som årsak for sykemelding, Norden sett under ett, men en tendens til økt aksept ved økende bedriftsstørrelse.

Det å ha vanskeligheter i forbindelse med samlivsbrudd aksepteres i lavere grad som en årsak til sykemelding ved økende antall timer man arbeider, Norden sett under ett, og det er de som arbeider 40 timer eller mer som skiller seg spesielt ut. Det oppnås en index på 42 blant de som arbeider 8 - 31 timer i uken, mens det oppnås en index på 38 blant de som arbeider 40 timer eller mer i uken.

Når man ser på aksepten blant ulike yrkesgrupper i Norden under ett, finner vi at aksepten for det å ha vanskeligheter i forbindelse med samlivsbrudd som en årsak til sykemelding er lavest blant arbeidstagere med følgende yrker: Jordbruk/skogbruk/fiske (index 33), andre serviceyrker, herunder reiseliv (index 35) og industriarbeid (index 36). Den er høyest blant de som arbeider som megler/konsulent/rådgiver (index 44). 


\subsection{Akseptable årsaker for å sykemelde seg - ”Føler ubehag pga. stress på arbeidet”}

Neste årsak til sykemelding vi skal ta for oss er det å føle ubehag pga. stress på arbeidet Figuren nedenfor vises hvordan denne årsaken aksepteres i de ulike landene.

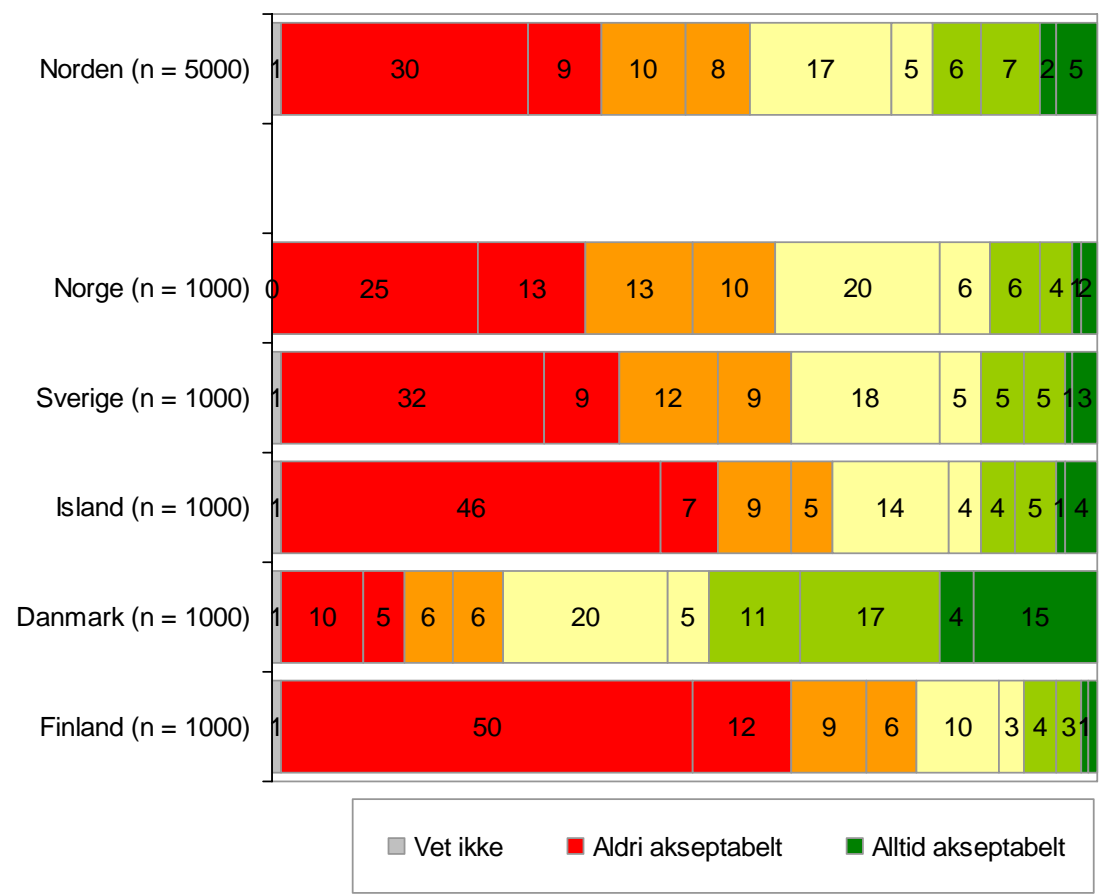

Vi ser store forskjeller fra land når det gjelder hvor akseptabelt det å føle ubehag pga. stress på arbeidet er som årsak til sykemelding. Denne årsaken er klart mest akseptert i Danmark. I Danmark synes $15 \%$ at dette alltid er en akseptabel årsak til sykemelding, mens 10 \% synes årsaken aldri kan aksepteres (index 55). Finner er de som i minst grad aksepterer det å føle ubehag pga. stress på arbeidet som årsak til sykemelding. $1 \%$ av finnene synes alltid dette er en akseptabel årsak til sykemelding, mens 50 \% synes årsaken aldri er akseptabel (index 18).

Det er ingen forskjeller mellom menn og kvinner når det gjelder å akseptere det å føle ubehag pga. stress på arbeidet som årsak for sykemelding, Norden sett under ett.

De yngste og de eldste er de som i minst grad aksepterer det å føle ubehag pga. stress på arbeidet som årsak for sykemelding, Norden sett under ett. Det oppnås en index på 31 blant de som er under 30 år og de som er 50 år eller eldre, mens det oppnås en index på 34 i de mellomste aldersgruppene. 
Det er ingen systematiske forskjeller mellom utdanningsgrupper når det gjelder å akseptere det å føle ubehag pga. stress på arbeidet som årsak for sykemelding, Norden sett under ett.

De som arbeider i offentlig sektor aksepterer denne årsaken i noe høyere grad enn de som arbeider i privat sektor, Norden sett under ett. Det oppnås en index på 34 blant de som arbeider i offentlig sektor, mens det oppnås en index på 32 blant de som arbeider i privat sektor. Klart lavest aksept er det blant selvstendig næringsdrivende (index 23).

I Norden sett under ett aksepteres det å føle ubehag pga. stress på arbeidet i høyere grad som en årsak til sykemelding ved økende størrelse på bedriften arbeidstagerne jobber i (økende antall ansatte). Det oppnås en index på 30 blant de som arbeider i bedrifter med under 15 ansatte, mens det oppnås en index på 35 blant de som arbeider i bedrifter med 200 ansatte eller mer.

Det å føle ubehag pga. stress på arbeidet aksepteres i lavere grad som en årsak til sykemelding ved økende antall timer man arbeider, Norden sett under ett, og det er de som arbeider 40 timer eller mer som skiller seg spesielt ut. Det oppnås en index på 35 blant de som arbeider 8 - 31 timer i uken, mens det oppnås en index på 29 blant de som arbeider 40 timer eller mer i uken.

Når man ser på aksepten blant ulike yrkesgrupper i Norden under ett, finner vi at aksepten for det å føle ubehag pga. stress på arbeidet som en årsak til sykemelding er lavest blant arbeidstagere med følgende yrker: Jordbruk/skogbruk/fiske (index 28), transport (index 28), industriarbeid (index 28) og butikk- og salgsarbeid (index 28). Den er høyest blant de som arbeider som megler/konsulent/rådgiver (index 39) og de som arbeider innen gruppen ingeniør/IT/telekommunikasjon (index 36) 


\subsection{Akseptable årsaker for å sykemelde seg - ”Har problemer med å komme seg på jobb pga. kortvarig manglende tilbud i barnehage, skole eller offentlig transport”}

Neste årsak til sykemelding vi skal ta for oss er det å ha problemer med å komme seg på jobb pga. kortvarig manglende tilbud i barnehage, skole eller offentlig transport. Figuren nedenfor vises hvordan denne årsaken aksepteres i de ulike landene.

Spørsmål: Det er akseptabelt å sykemelde seg når man har problemer med å komme seg på jobb på grunn av kortvarig manglende tilbud i barnehage, skole eller offentlig transport

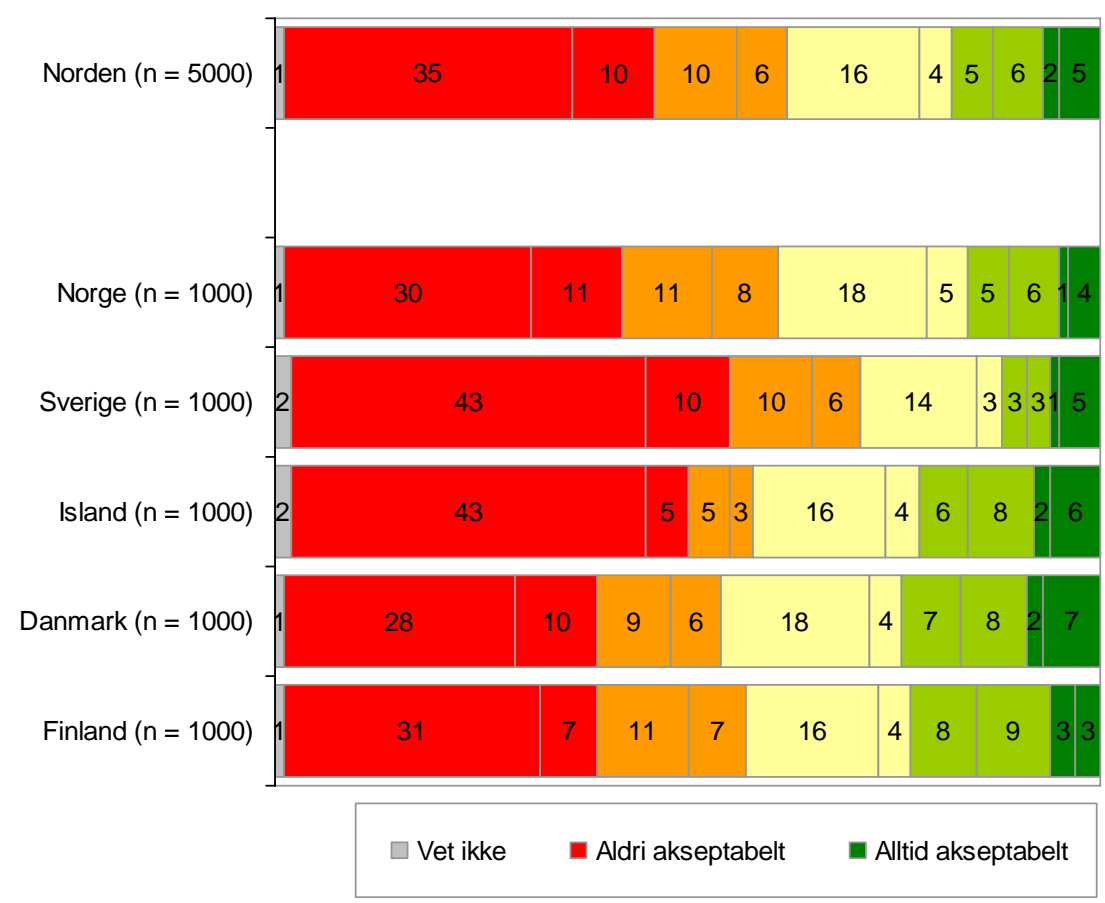

Vi ser en del forskjeller fra land når det gjelder hvor akseptabelt det å ha problemer med å komme seg på jobb pga. kortvarig manglende tilbud i barnehage, skole eller offentlig transport er som årsak til sykemelding. Denne årsaken er mest akseptert i Danmark og i Finland. I Danmark synes $7 \%$ at dette alltid er en akseptabel årsak til sykemelding, mens $28 \%$ synes årsaken aldri kan aksepteres (index 35). I Finland synes $3 \%$ at dette alltid er en akseptabel årsak til sykemelding, mens 31 \% synes årsaken aldri kan aksepteres (index 33). Svensker er de som i minst grad aksepterer det å ha problemer med å komme seg på jobb pga. kortvarig manglende tilbud i barnehage, skole eller offentlig transport som årsak til sykemelding. $5 \%$ av svenskene synes alltid dette er en akseptabel årsak til sykemelding, mens en stor andel på 43 \% synes årsaken aldri er akseptabel (index 24).

Ser man på Norden under ett så aksepterer menn det å ha problemer med å komme seg på jobb pga. kortvarig manglende tilbud i barnehage, 
skole eller offentlig transport i noe høyere grad som årsak til sykemelding enn det kvinner gjør (index 33 mot 27).

Det er en nedgang $\mathrm{i}$ andelen som aksepterer denne årsaken som årsak for sykemelding ved økende alder. Det oppnås en index på 36 blant de som er mellom 18 år og 29 år gamle, mens det oppnås en index på 27 blant de som er mellom 50 år og 66 år gamle.

De med lavere utdanning aksepterer i høyere grad enn de med høyere utdanning det å ha problemer med å komme seg på jobb pga. kortvarig manglende tilbud i barnehage, skole eller offentlig transport som årsak for sykemelding, Norden sett under ett. Det oppnås en index på 32 blant de som har laves utdanning, mens det oppnås en index på 29 blant de som har høyest utdanning.

De som arbeider i privat sektor aksepterer denne årsaken i noe høyere grad enn de som arbeider i offentlig sektor, Norden sett under ett. Det oppnås en index på 31 blant de som arbeider i privat sektor, mens det oppnås en index på 27 blant de som arbeider i privat sektor.

Det er kun små forskjeller mellom de som arbeider i bedrifter med få ansatte og de som arbeider i større bedrifter når det gjelder å akseptere denne årsaken som årsak for sykemelding, Norden sett under ett.

Det er kun små forskjeller mellom de som arbeider få timer i uken og de som arbeider mange timer i uken når det gjelder å akseptere denne årsaken som årsak for sykemelding, Norden sett under ett.

Når man ser på aksepten blant ulike yrkesgrupper i Norden under ett, finner vi at aksepten for det å ha problemer med å komme seg på jobb pga. kortvarig manglende tilbud i barnehage, skole eller offentlig transport som en årsak til sykemelding er lavest blant arbeidstagere med følgende yrker: Helse/pleie/omsorg (index 24), ledere (index 28) og undervisning inkl. barnehage (index 28). Den er høyest blant de som arbeider innen bygg og anlegg (index 35). 


\subsection{Akseptable årsaker for å sykemelde seg - ”Er misfornøyd med forhold på arbeidsplassen”}

En av de årsakene som relativt få aksepterer som årsak for sykemelding var som vi så det å være misfornøyd med forhold på arbeidsplassen. Figuren nedenfor vises hvordan denne årsaken aksepteres i de ulike landene.

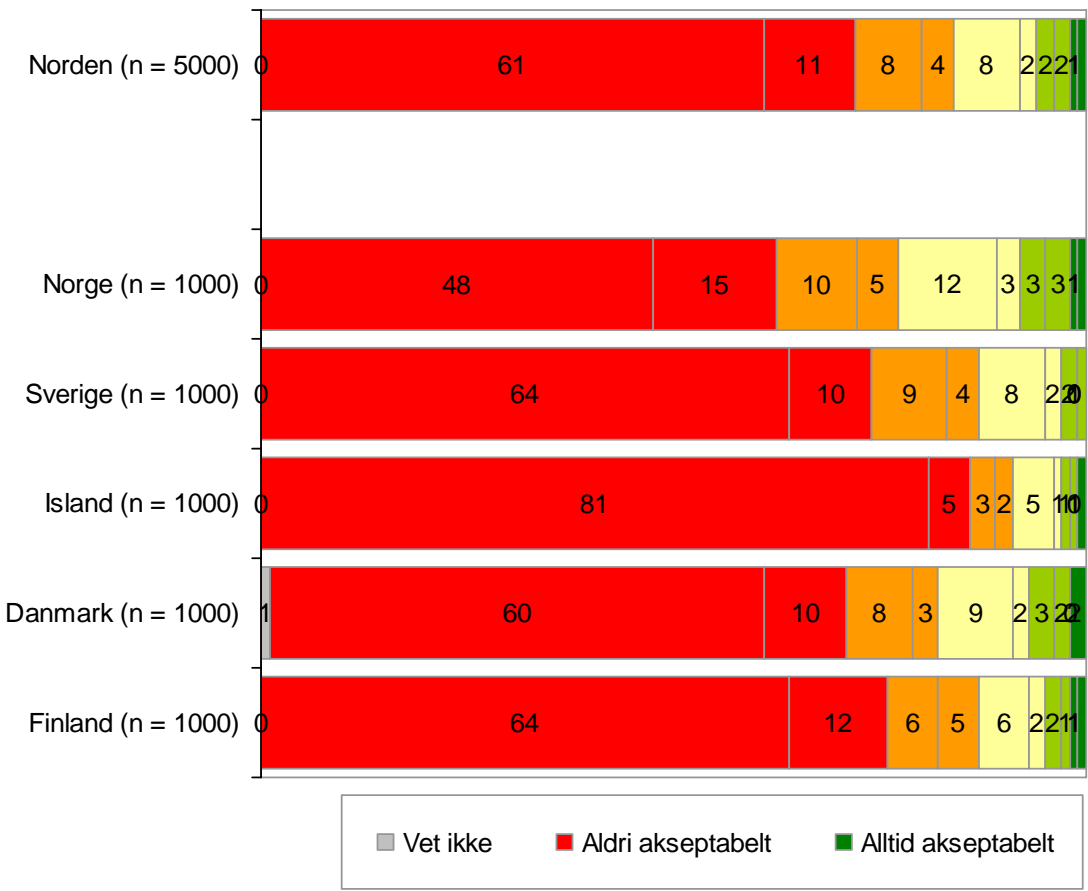

Vi ser også her en del forskjeller fra land når det gjelder hvor akseptabelt det å være misfornøyd med forhold på arbeidsplassen er som årsak til sykemelding. Denne årsaken er mest akseptert i Norge og i Danmark. I Norge synes $1 \%$ at dette alltid er en akseptabel årsak til sykemelding, mens $48 \%$ synes årsaken aldri kan aksepteres (index 18). I Danmark synes $2 \%$ at dette alltid er en akseptabel årsak til sykemelding, mens 60 $\%$ synes årsaken aldri kan aksepteres (index 15). Islendinger er de som $\mathrm{i}$ minst grad aksepterer det å være misfornøyd med forhold på arbeidsplassen som årsak til sykemelding. $1 \%$ av islendingene synes alltid dette er en akseptabel årsak til sykemelding, mens hele 81 \% synes årsaken aldri er akseptabel (index 7).

Det er ingen forskjeller mellom menn og kvinner når det gjelder å akseptere det å være misfornøyd med forhold på arbeidsplassen som årsak for sykemelding, Norden sett under ett.

Det er de som er under 30 år gamle som i størst grad aksepterer denne årsaken, men forskjellene er små mellom aldersgruppene, Norden sett under ett. Det oppnås en index på 16 blant de yngste, mens det oppnås en index på 13 blant de med alder mellom 50 år og 65 år. 
Det å være misfornøyd med forhold på arbeidsplassen aksepteres i mindre grad som en årsak til sykemelding ved økende utdanning i Norden sett under ett. Det oppnås en index på 16 blant de som har lavest utdanning, mens det oppnås en index på 11 blant de som har høyest utdanning.

Det er kun små forskjeller mellom de som arbeider i privat sektor og de som arbeider i offentlig sektor når det gjelder å akseptere denne årsaken som årsak for sykemelding, Norden sett under ett. De som er selvstendig næringsdrivende skiller seg heller ikke ut.

Det er kun små forskjeller mellom de som arbeider i bedrifter med få ansatte og de som arbeider i større bedrifter når det gjelder å akseptere denne årsaken som årsak for sykemelding, Norden sett under ett.

Det å være misfornøyd med forhold på arbeidsplassen aksepteres i lavere grad som en årsak til sykemelding ved økende antall timer man arbeider, Norden sett under ett. Det oppnås en index på 16 blant de som arbeider 8 - 31 timer i uken, mens det oppnås en index på 12 blant de som arbeider 40 timer eller mer i uken.

Når man ser på aksepten blant ulike yrkesgrupper i Norden under ett, finner vi at aksepten for det å være misfornøyd med forhold på arbeidsplassen som en årsak til sykemelding er lavest blant arbeidstagere med følgende yrker: Ledere (index 11) og meglere/konsulenter/rådgivere (index 11). Den er høyest blant de som arbeider innen jordbruk/skogbruk/fiske (index 17) og innen hotell/kafé/restaurant (index 17). 


\subsection{Akseptable årsaker for å sykemelde seg - ”Har fått for lite søvn”}

Den nest minst aksepterte årsaken for å sykmelde seg er det å ha fått for lite søvn. Figuren nedenfor vises hvordan denne årsaken aksepteres i de ulike landene.

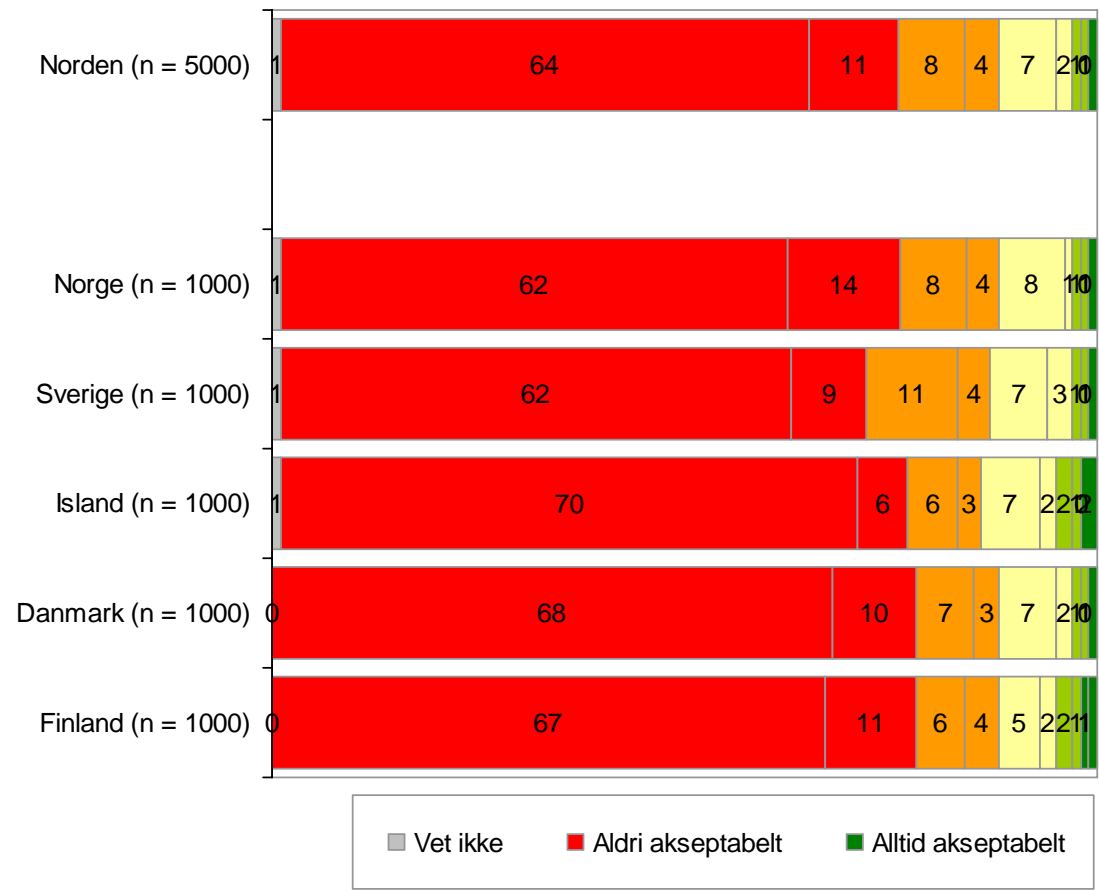

Det er svært små forskjeller fra land når det gjelder hvor akseptabelt det å ha fått for lite søvn er som årsak til sykemelding. Sverige oppnår her en index på 12, mens Danmark kommer ut med en index på 10. Tilnærmet ingen aksepterer denne årsaken alltid, mens mellom 62 \% (i Norge og i Sverige) og 70 \% (på Island) aldri aksepterer denne årsaken.

Ser man på Norden under ett så aksepterer menn det å ha fått for lite søvn i noe høyere grad som årsak til sykemelding enn det kvinner gjør (index 12 mot 10).

Det er kun små forskjeller mellom de ulike aldersgruppene når det gjelder å akseptere denne årsaken som årsak for sykemelding, Norden sett under ett.

Det å ha fått for lite søvn aksepteres i noe økende grad som en årsak til sykemelding ved økende utdanning i Norden sett under ett. Det oppnås en index på 10 blant de som har lavest utdanning, mens det oppnås en index på 13 blant de som har høyest utdanning.

De som arbeider i privat sektor aksepterer denne årsaken i noe høyere grad enn de som arbeider i offentlig sektor, Norden sett under ett. Det 
oppnås en index på 12 blant de som arbeider i privat sektor, mens det oppnås en index på 10 blant de som arbeider i privat sektor.

Det er kun små forskjeller mellom de som arbeider i bedrifter med få ansatte og de som arbeider i større bedrifter når det gjelder å akseptere denne årsaken som årsak for sykemelding, Norden sett under ett, men en tendens til at de som arbeider i de største bedriftene aksepterer denne årsaken i høyest grad.

Det er kun små forskjeller mellom de som arbeider få timer i uken og de som arbeider mange timer i uken når det gjelder å akseptere denne årsaken som årsak for sykemelding, Norden sett under ett.

Når man ser på aksepten blant ulike yrkesgrupper i Norden under ett, finner vi at aksepten for det å ha fått for lite søvn som en årsak til sykemelding er lavest blant arbeidstagere med følgende yrker: Butikk- og salgsarbeid (index 8), hotell/kafé/restaurant (index 9) og jordbruk/skogbruk/fiske (index 9). Den er høyest blant de som arbeider innen ingeniør/IT/telekommunikasjon (index 14).

\subsection{Akseptable årsaker for å sykemelde seg - ”Føler seg dårlig etter å ha drukket mye alkohol kvelden før”}

Den minst aksepterte årsaken for å sykmelde seg er det å føle seg dårlig etter å ha drukket mye alkohol kvelden før. Figuren nedenfor vises hvordan denne årsaken aksepteres i de ulike landene.

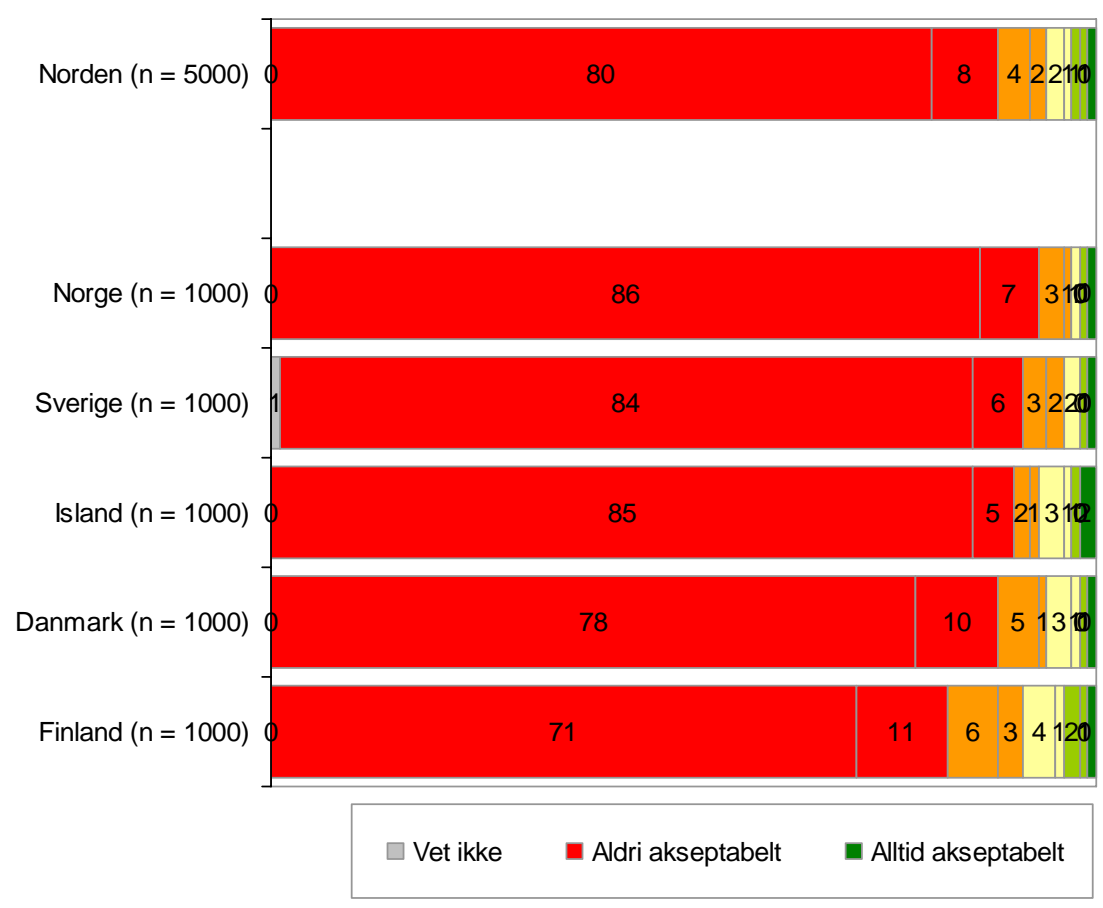


Det er små forskjeller fra land når det gjelder hvor akseptabelt det å føle seg dårlig etter å ha drukket mye alkohol kvelden før er som årsak til sykemelding. Denne årsaken er mest akseptert i Finland. I Finland synes $1 \%$ at dette alltid er en akseptabel årsak til sykemelding, mens $71 \%$ synes årsaken aldri kan aksepteres (index 9). Nordmenn er de som i minst grad aksepterer det å føle seg dårlig etter å ha drukket mye alkohol kvelden før som årsak til sykemelding. $1 \%$ av nordmennene synes alltid dette er en akseptabel årsak til sykemelding, mens hele 86 \% synes årsaken aldri er akseptabel (index 4).

Ser man på Norden under ett så aksepterer menn det å føle seg dårlig etter å ha drukket mye alkohol kvelden før i noe høyere grad som årsak til sykemelding enn det kvinner gjør (index 7 mot 5).

Det er ingen forskjeller mellom de ulike aldersgruppene når det gjelder å akseptere denne årsaken som årsak for sykemelding, Norden sett under ett.

Det er ingen forskjeller mellom de ulike utdanningsgruppene når det gjelder å akseptere denne årsaken som årsak for sykemelding, Norden sett under ett.

Det er ingen forskjeller mellom de som arbeider i privat sektor og de som arbeider i offentlig sektor når det gjelder å akseptere denne årsaken som årsak for sykemelding, Norden sett under ett. De som er selvstendig næringsdrivende skiller seg heller ikke ut.

Det er ingen forskjeller mellom de som arbeider i små bedrifter og de som arbeider større bedrifter når det gjelder å akseptere denne årsaken som årsak for sykemelding, Norden sett under ett.

Det er ingen forskjeller mellom de som arbeider få timer i uken og de som arbeider mange timer i uken når det gjelder å akseptere denne årsaken som årsak for sykemelding, Norden sett under ett.

Det er kun små forskjeller mellom de ulike yrkesgruppene når det gjelder det å akseptere det å føle seg dårlig etter å ha drukket mye alkohol kvelden før som årsak for sykemelding, men de som arbeider innen to ulike yrker aksepterer denne årsaken litt mer enn de andre. Det er de som arbeider innen gruppen ingeniør/IT/telekommunikasjon (index 9) og de som arbeider innen hotell/kafé/restaurant (index 8). 


\section{Akseptabel lengde på sykemelding}

De arbeidstagerne som aksepterte de ulike årsakene for å sykemelde seg fikk et oppfølgingsspørsmål om hvor lenge en sykemelding etter deres mening kunne godtas. Oppfølgingsspørsmålet ble knyttet til seks av årsakene. Resultatene fra disse spørsmålene presenteres nedenfor for Norden samlet.

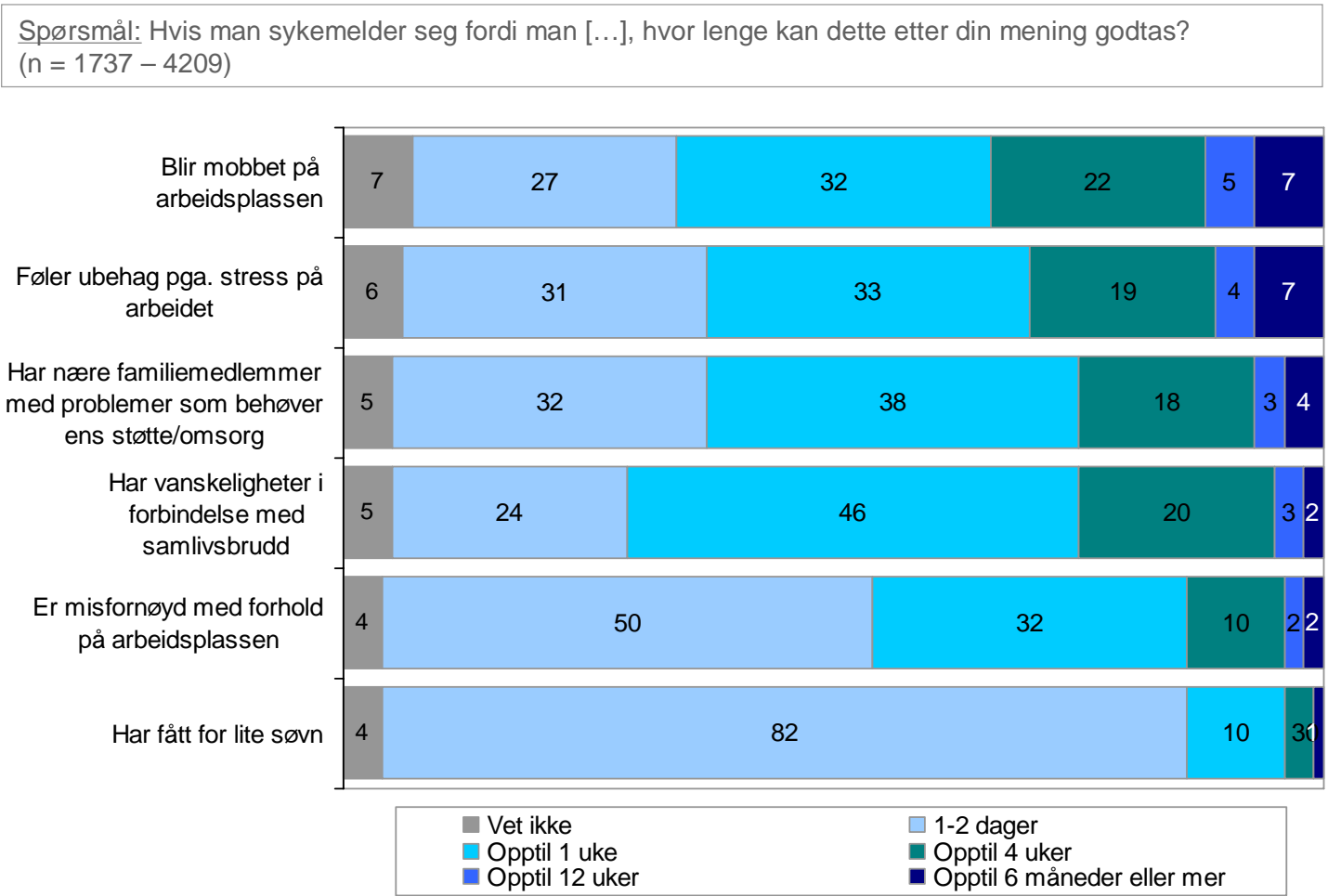

Den årsaken man godtar lengst sykemelding for er det å bli mobbet på arbeidsplassen. I gjennomsnitt godtar man 21 dagers sykemelding knyttet til denne årsaken2. Den årsaken man godtar nest lengst sykemelding for er det å føle ubehag pga. stress på arbeidet. I gjennomsnitt godtar man 19 dagers sykemelding knyttet til denne årsaken.

Den årsaken man godtar kortest sykemelding for er det å ha fått for lite søvn. I gjennomsnitt godtar man 4 dagers sykemelding knyttet til den-

\footnotetext{
${ }^{2}$ For lettere å kunne sammenligne resultatene mellom ulike undergrupper og mellom land er det utarbeidet en gjennomsnittscore der 1 - 2 dager er kodet med 1,5 dager, opptil 1 uke er kodet med 3,5 dager, opptil 4 uker er kodet med 14 dager og opptil 6 måneder eller mer er kodet til 182 dager
} 
ne årsaken. Når det gjelder det å være misfornøyd med forhold på arbeidsplassen godtar man i gjennomsnitt 7 dagers sykemelding.

Det er relativt små forskjeller mellom de ulike landene når det gjelder rangeringen av de ulike årsakene når det gjelder hvor lenge en sykemelding kan godtas, med unntak av Island som bla. rangerer det å ha nære familiemedlemmer som behøver ens støtte/omsorg på topp.

Hvis vi ser på de seks årsakene til sykemelding under ett, og regner ut et gjennomsnitt av antall dager sykemelding som kan godtas ser vi at arbeidstagere i Danmark og i Norge er de som i gjennomsnitt godtar flest sykemeldingsdager, uavhengig av årsak. 17 dager i Danmark og 16 dager i Norge. Arbeidstagere i Finland og på Island er de som i gjennomsnitt godtar færrest sykemeldingsdager, uavhengig av årsak. Syv dager i Finland og seks dager på Island.

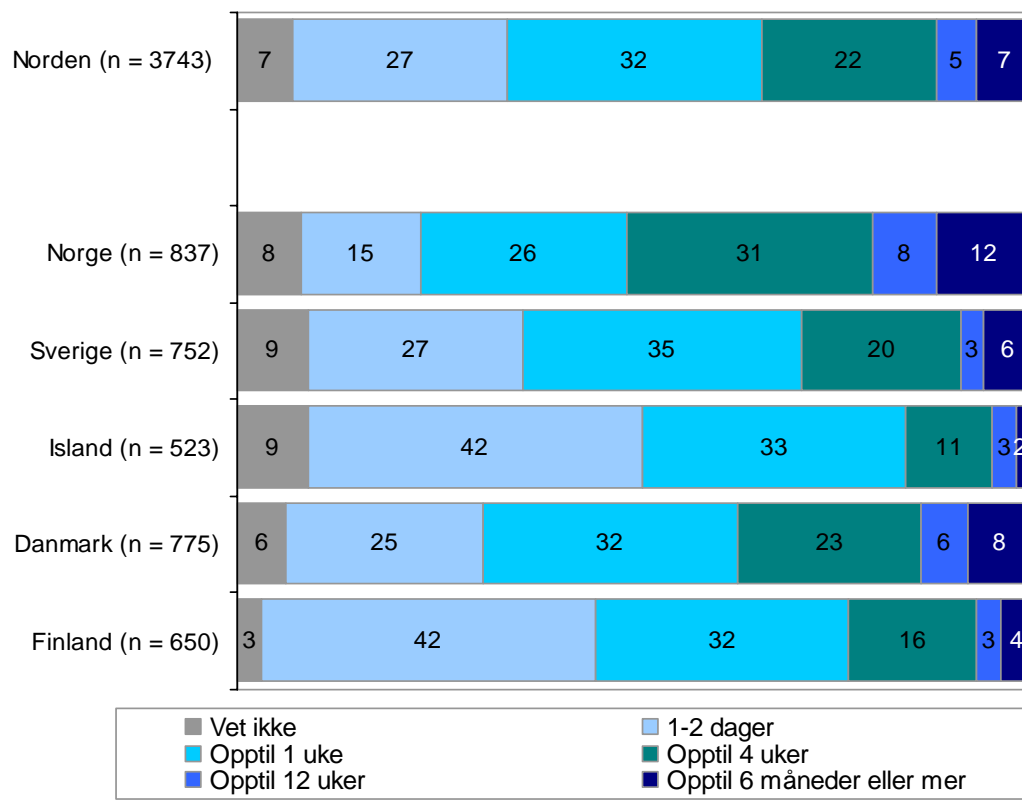

\subsection{Akseptabel lengde på sykemelding - ”Blir mobbet på arbeidsplassen”}

Den årsaken man godtar lengst sykemeldingslengde for var det å bli mobbet på arbeidsplassen. La oss se hvor lang sykemeldingslengde som godtas i de ulike landene.

Som vi ser av figuren ovenfor er det klare forskjeller fra land når det gjelder hvor lenge en sykemelding kan godtas hvis man blir mobbet på arbeidsplassen. Norske arbeidstagere er de som godtar flest sykemel- 
dingsdager med 34 dager i gjennomsnitt. Deretter kommer danske arbeidstagere med 22 dager. Islandske arbeidstagere godtar færrest sykemeldingsdager med 9 dager.

Ser man på Norden under ett så godtar kvinner flere sykemeldingsdager knyttet til det å bli mobbet på arbeidsplassen enn det menn gjør (24 mot 18 dager).

De under 30 år og de mellom 50 år og 65 år godtar færre dagers sykemelding knyttet til denne årsaken enn det de mellom 30 år og 50 år gjør.(17/19 mot 24 dager).

De med høyest utdanning er de som godtar flest sykemeldingsdager knyttet til det å bli mobbet på arbeidsplassen, Norden sett under ett (27 dager).

Ser man på Norden under ett så godtar de som arbeider i offentlig sektor flere sykemeldingsdager knyttet til det å bli mobbet på arbeidsplassen enn det de som arbeider i privat sektor gjør (25 mot 19 dager). De som er selvstendig næringsdrivende godtar bare seks dager.

Det er ingen systematiske forskjeller mellom de som arbeider i en bedrift med få ansatte og de som arbeider i en bedrift med flere ansatte når det gjelder antall sykemeldingsdager som godtas knyttet til det å bli mobbet på arbeidsplassen.

De som arbeider få timer i uken godtar flere sykemeldingsdager knyttet til det å bli mobbet på arbeidsplassen enn det de som arbeider mange timer i uken gjør, Norden sett under ett. De som arbeider 8 - 31 timer i uken godtar 27 dager, mens de som arbeider 40 timer i uken eller mer godtar 18 dager.

Når man ser på antall sykemeldingsdager som kan godtas blant ulike yrkesgrupper i Norden under ett, finner vi at antall sykemeldingsdager som kan godtas knyttet til det å bli mobbet på arbeidsplassen er lavest blant arbeidstagere med følgende yrker: Jordbruk/skogbruk/fiske (11 dager) og håndverksyrker (12 dager). Den er høyest blant følgende yrker: undervisning inkl. barnehage (29 dager) og megler/konsulent/rådgiver (28 dager).

\subsection{Akseptabel lengde på sykemelding - ”Føler ubehag pga. stress på arbeidet”}

Den årsaken man godtar nest lengst sykemeldingslengde for var det å føle ubehag pga. stress på arbeidet. Nedenfor vises hvor lang sykemeldingslengde som godtas i de ulike landene. 
Som vi ser av figuren ovenfor er det klare forskjeller fra land når det gjelder hvor lenge en sykemelding kan godtas hvis man føler ubehag pga. stress på arbeidet, og det er Danmark som først og fremst skiller seg ut. Danske arbeidstagere er de som godtar flest sykemeldingsdager med 39 dager i gjennomsnitt. Deretter kommer norske arbeidstagere med 13 dager. Islandske arbeidstagere godtar færrest sykemeldingsdager med 5 dager.

Ser man på Norden under ett så godtar kvinner flere sykemeldingsdager knyttet til det å føle ubehag pga. stress på arbeidet enn det menn gjør (21 mot 16 dager).

De under 30 år og de mellom 50 år og 65 år godtar færre dagers sykemelding knyttet til denne årsaken enn det de mellom 30 år og 50 år gjør.(13/17 mot 22 dager).

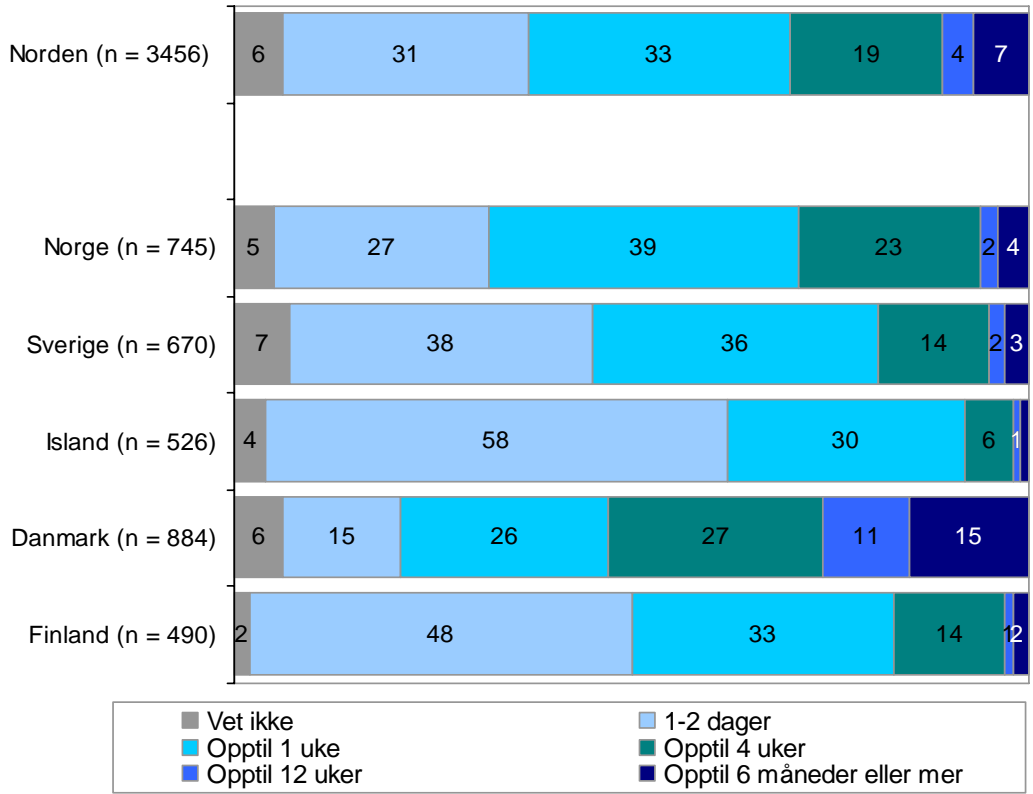

De med høyest utdanning er de som godtar flest sykemeldingsdager knyttet til det å føle ubehag pga. stress på arbeidet, Norden sett under ett (21 dager).

Ser man på Norden under ett så er det små forskjeller mellom de som arbeider i privat sektor og de som arbeider i offentlig sektor når det gjelder hvor mange sykemeldingsdager som godtas knyttet til det å føle ubehag pga. stress på arbeidet (19 - 20 dager). De som er selvstendig næringsdrivende godtar imidlertid bare 10 dager.

De som arbeider i bedrifter med færre enn 15 ansatte godtar noen færre sykemeldingsdager knyttet til denne årsaken enn de som arbeider i større bedrifter (17 mot 20 dager).

De som arbeider få timer i uken godtar flere sykemeldingsdager knyttet til det å føle ubehag pga. stress enn det de som arbeider mange timer i 
uken gjør, Norden sett under ett. De som arbeider 8 - 31 timer i uken godtar 22 dager, mens de som arbeider 40 timer i uken eller mer godtar 14 dager.

Når man ser på antall sykemeldingsdager som kan godtas blant ulike yrkesgrupper i Norden under ett, finner vi at antall sykemeldingsdager som kan godtas knyttet til det å føle ubehag pga. stress på arbeidet er lavest blant arbeidstagere med følgende yrker: Jordbruk/skogbruk/fiske ( 9 dager) og industriarbeid (11 dager). Den er høyest blant følgende yrker: megler/konsulent/rådgiver (32 dager) og håndverksyrker (28 dager).

\subsection{Akseptabel lengde på sykemelding - ”Har nære familiemedlemmer med problemer som behøver ens støtte/omsorg”}

Den neste årsaken vi skal ta for oss er det å ha nære familiemedlemmer med problemer som behøver ens støtte/omsorg. Nedenfor vises hvor lang sykemeldingslengde som godtas i de ulike landene.

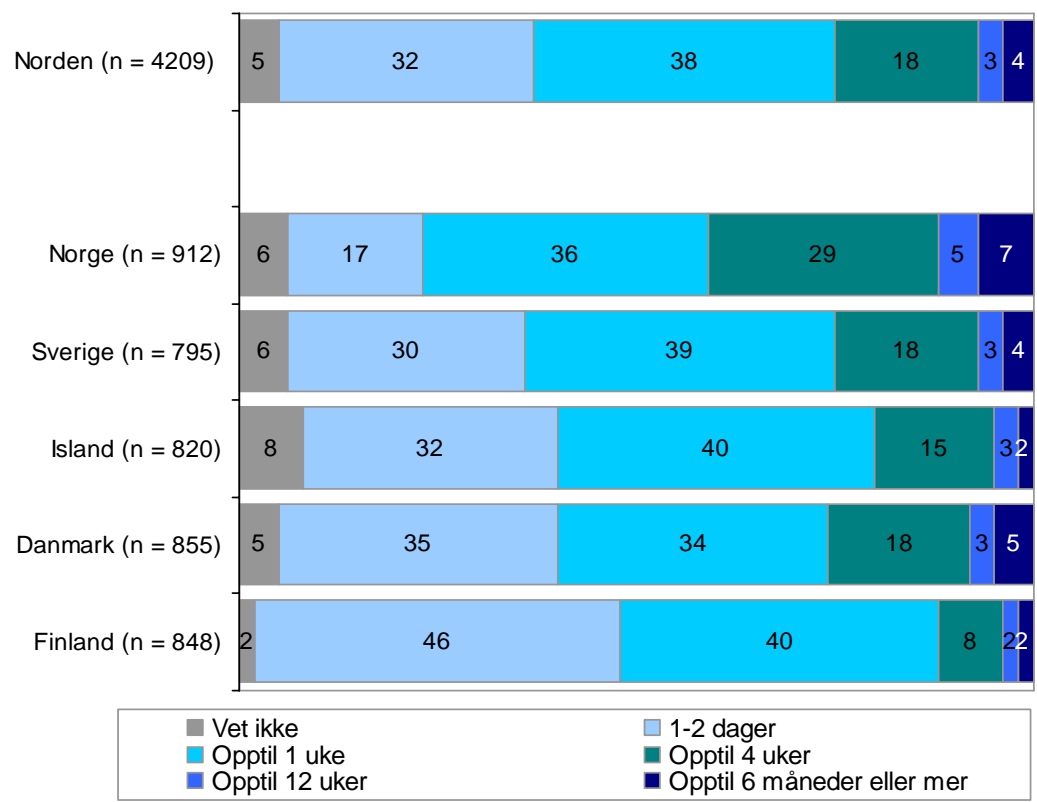

Som vi ser av figuren ovenfor er det også her klare forskjeller fra land til land når det gjelder hvor lenge en sykemelding kan godtas hvis man har nære familiemedlemmer med problemer som behøver ens støtte/omsorg. Norske arbeidstagere er de som godtar flest sykemeldingsdager med 21 dager. Deretter kommer danske arbeidstagere med 16 dager. Finske arbeidstagere godtar færrest sykemeldingsdager med 7 dager. 
Ser man på Norden under ett så godtar menn flere sykemeldingsdager knyttet til det å ha nære familiemedlemmer med problemer som behøver ens støtte/omsorg enn det kvinner gjør (15 mot 13 dager).

De under 30 år og de mellom 50 år og 65 år godtar færre dagers sykemelding knyttet til denne årsaken enn det de mellom 30 år og 50 år gjør.(12/13 mot 16 dager).

Det er ingen systematiske forskjeller mellom utdanningsgruppene når det gjelder hvor mange dagers sykemelding man godtar knyttet til denne årsaken, Norden sett under ett.

Ser man på Norden under ett så godtar de som arbeider i offentlig sektor flere sykemeldingsdager knyttet til det å ha nære familiemedlemmer med problemer som behøver ens støtte/omsorg enn det de som arbeider i privat sektor gjør (15 mot 13 dager). De som er selvstendig næringsdrivende godtar 17 dager.

Det er ingen systematiske forskjeller mellom de som arbeider i små eller større bedrifter når det gjelder hvor mange dagers sykemelding man godtar knyttet til denne årsaken, Norden sett under ett.

De som arbeider få timer i uken godtar flere sykemeldingsdager knyttet til det å ha nære familiemedlemmer med problemer som behøver ens støtte/omsorg enn det de som arbeider mange timer i uken gjør, Norden sett under ett. De som arbeider 8 - 31 timer i uken godtar 19 dager, mens de som arbeider 40 timer i uken eller mer godtar 13 dager.

Når man ser på antall sykemeldingsdager som kan godtas blant ulike yrkesgrupper i Norden under ett, finner vi at antall sykemeldingsdager som kan godtas knyttet til det å ha nære familiemedlemmer med problemer som behøver ens støtte/omsorg er lavest blant arbeidstagere med følgende yrker: Jordbruk/skogbruk/fiske (8 dager) og håndverksyrker (9 dager). Den er høyest blant følgende yrker: undervisning inkl. barnehage (19 dager) og transport (18 dager). 


\subsection{Akseptabel lengde på sykemelding - "Har vanskelig- heter i forbindelse med samlivsbrudd"}

Den neste årsaken vi skal ta for oss er det å ha vanskeligheter i forbindelse med samlivsbrudd. Nedenfor vises hvor lang sykemeldingslengde som godtas i de ulike landene.

Spørsmål: Hvis man sykemelder seg fordi man har vanskeligheter i forbindelse med samlivsbrudd, hvor

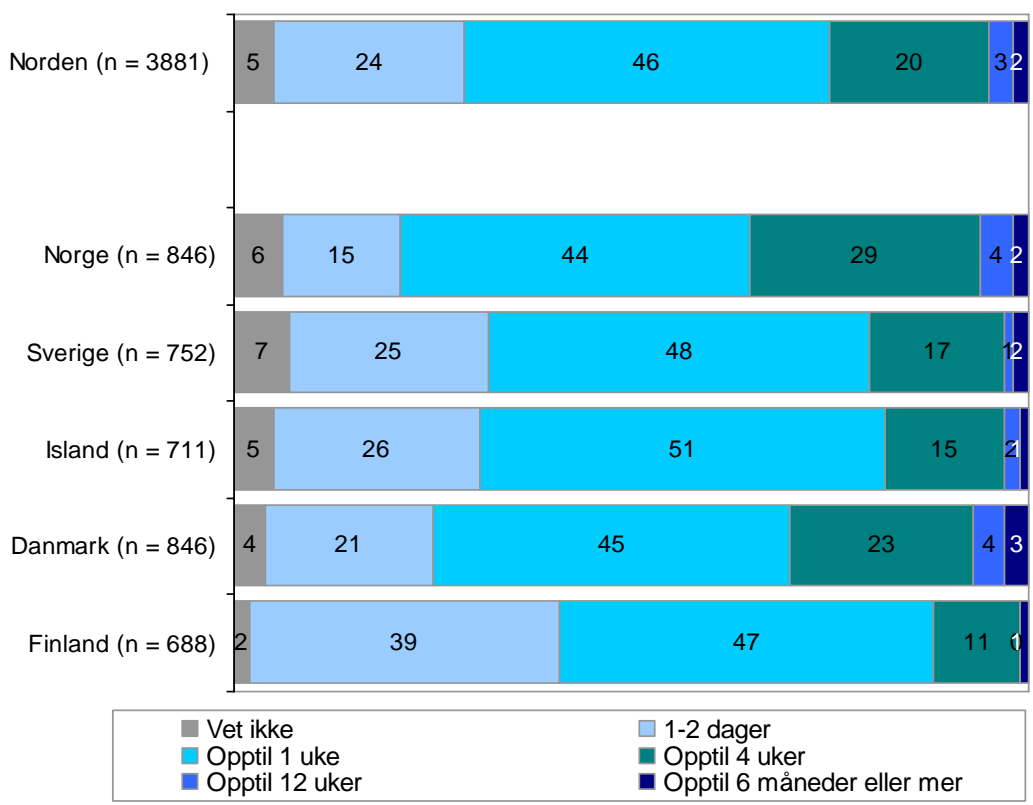

Det er mindre forskjeller fra land når det gjelder hvor lenge en sykemelding kan godtas hvis man har vanskeligheter i forbindelse med samlivsbrudd. Danske arbeidstagere er de som godtar flest sykemeldingsdager med 13 dager. Deretter kommer norske arbeidstagere med 12 dager. Islandske og finske arbeidstagere godtar færrest sykemeldingsdager med 6 dager.Ser man på Norden under ett så godtar kvinner flere sykemeldingsdager knyttet til det å ha vanskeligheter i forbindelse med samlivsbrudd enn det menn gjør (11 mot 9 dager).

De som er under 30 år er de som godtar færrest dagers sykemelding knyttet til denne årsaken, nemlig 8 dager.

Det er ingen systematiske forskjeller mellom utdanningsgruppene når det gjelder hvor mange dagers sykemelding man godtar knyttet til denne årsaken, Norden sett under ett.

Ser man på Norden under ett så godtar de som arbeider i offentlig sektor flere sykemeldingsdager knyttet til det å ha vanskeligheter i forbindelse med samlivsbrudd enn det de som arbeider i privat sektor gjør (12 mot 9 dager). De som er selvstendig næringsdrivende godtar bare seks dager.

Det er små forskjeller mellom de som arbeider i små eller større bedrifter når det gjelder hvor mange dagers sykemelding man godtar knyttet til denne årsaken, Norden sett under ett. 
De som arbeider få timer i uken godtar flere sykemeldingsdager knyttet til det å ha vanskeligheter i forbindelse med samlivsbrudd enn det de som arbeider mange timer i uken gjør, Norden sett under ett. De som arbeider 8-31 timer i uken godtar 14 dager, mens de som arbeider 40 timer i uken eller mer godtar 8 dager.

Når man ser på antall sykemeldingsdager som kan godtas blant ulike yrkesgrupper i Norden under ett, finner vi at antall sykemeldingsdager som kan godtas knyttet til det å ha vanskeligheter i forbindelse med samlivsbrudd er lavest blant meglere/konsulenter/rådgivere (6 dager). Den er høyest blant de som arbeider innen helse/pleie/omsorg (13 dager).

\subsection{Akseptabel lengde på sykemelding - ’Er misfornøyd med forhold på arbeidsplassen”}

Den neste årsaken vi skal ta for oss er det å være misfornøyd med forhold på arbeidsplassen. Nedenfor vises hvor lang sykemeldingslengde som godtas i de ulike landene.

Spørsmål: Hvis man sykemelder seg fordi man er misfornøyd med forhold på arbeidsplassen, hvor lenge kan dette etter din mening godtas?

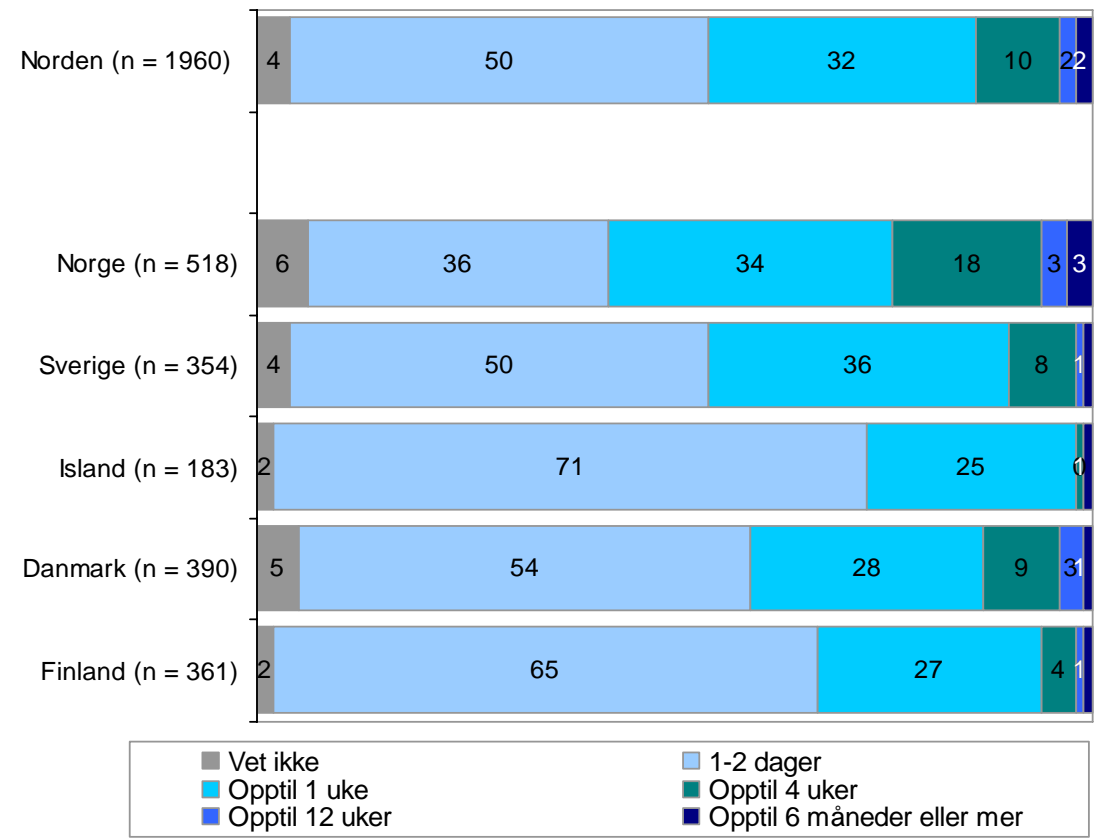

Det er noen forskjeller fra land når det gjelder hvor lenge en sykemelding kan godtas hvis man er misfornøyd med forhold på arbeidsplassen, spesielt skiller Norge seg ut. Norske arbeidstagere er de som godtar flest sykemeldingsdager med 12 dager. Deretter kommer danske arbeidstagere med syv dager. Islandske og finske arbeidstagere godtar færrest sykemeldingsdager med henholdsvis tre og fem dager. 
Det er ingen forskjell mellom menn og kvinner når det gjelder hvor mange dagers sykemelding man godtar knyttet til det å være misfornøyd med forhold på arbeidsplassen.

Det er ingen forskjell mellom ulike aldersgrupper når det gjelder hvor mange dagers sykemelding man godtar knyttet til det å være misfornøyd med forhold på arbeidsplassen.

De som har lavest utdanning godtar flere dagers sykemelding knyttet til denne årsaken enn det de med høy utdanning gjør, Norden sett under ett. De som har lavest utdanning godtar 10 dager, mens de med høyest utdanning godtar 6 dager.

Det er ingen forskjell mellom de som arbeider i privat sektor og de som arbeider i offentlig sektor når det gjelder hvor mange dagers sykemelding man godtar knyttet til det å være misfornøyd med forhold på arbeidsplassen. De selvstendig næringsdrivende skiller seg ut ved bare å godta 3 dagers sykemelding.

Det er ingen systematiske forskjeller mellom de som arbeider i små eller større bedrifter når det gjelder hvor mange dagers sykemelding man godtar knyttet til denne årsaken, Norden sett under ett.

De som arbeider få timer i uken godtar flere sykemeldingsdager knyttet til det å være misfornøyd med forhold på arbeidsplassen enn det de som arbeider mange timer i uken gjør, Norden sett under ett. De som arbeider 8 - 31 timer i uken godtar 11 dager, mens de som arbeider 40 timer i uken eller mer godtar 5 dager.

Vi ser ingen forskjell mellom ulike yrkesgrupper når det gjelder hvor mange dagers sykemelding man godtar knyttet til det å være misfornøyd med forhold på arbeidsplassen da utvalget blir for lite per yrkesgruppe. 


\subsection{Akseptabel lengde på sykemelding - "Har fått for lite søvn”}

Den årsaken der man godtar færrest sykemeldingsdager er det å ha fått for lite søvn. Nedenfor vises hvor lang sykemeldingslengde som godtas i de ulike landene.

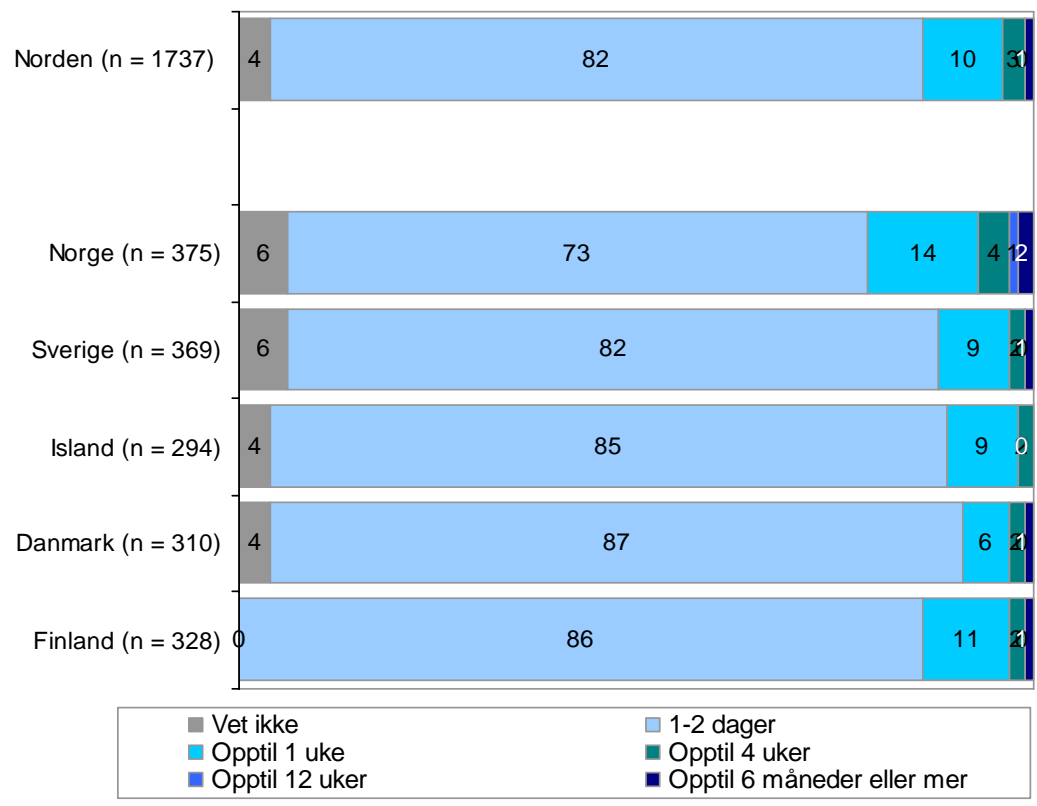

Det er små forskjeller fra land når det gjelder hvor lenge en sykemelding kan godtas hvis man har fått for lite søvn. Norske arbeidstagere er de som godtar flest sykemeldingsdager med 6 dager. Islandske arbeidstagere godtar færrest sykemeldingsdager med kun to dager.

Det er ingen forskjell mellom menn og kvinner når det gjelder hvor mange dagers sykemelding man godtar knyttet til det å ha fått for lite søvn, Norden sett under ett.

Det er ingen forskjell mellom ulike aldersgrupper når det gjelder hvor mange dagers sykemelding man godtar knyttet til det å ha fått for lite søvn, Norden sett under ett.

Det er ingen forskjell mellom ulike utdanningsgrupper når det gjelder hvor mange dagers sykemelding man godtar knyttet til det å ha fått for lite søvn, Norden sett under ett.

Ser man på Norden under ett så godtar de som arbeider i offentlig sektor flere sykemeldingsdager knyttet til det å ha fått for lite søvn enn det de som arbeider i privat sektor gjør (5 mot 3 dager).

Det er ingen systematiske forskjeller mellom de som arbeider i små eller større bedrifter når det gjelder hvor mange dagers sykemelding man godtar knyttet til denne årsaken, Norden sett under ett. 
Det er ingen forskjell mellom de som arbeider få timer i uken og de som arbeider mange timer i uken når det gjelder hvor mange dagers sykemelding man godtar knyttet til det å ha fått for lite søvn, Norden sett under ett.

Vi ser ingen forskjell mellom ulike yrkesgrupper når det gjelder hvor mange dagers sykemelding man godtar knyttet til det å ha fått for lite søvn da utvalget blir for lite per yrkesgruppe. 



\section{Akseptable årsaker vs. godtatt lengde på sykemelding}

Ser vi på i hvilken grad arbeidstagerne i de ulike landene aksepterer ulike årsaker for å sykemelde seg opp mot hvor mange dager de i gjennomsnitt godtar en sykemelding får vi et bilde av de totale holdninger til sykefravær i de ulike landene. Resultatene for de ulike årsakene for sykemelding presenteres nedenfor. Spredningen mellom landene er svært forskjellig fra årsak til årsak.

Det er akseptabelt å sykemelde seg når man blir mobbet på arbeidsplassen

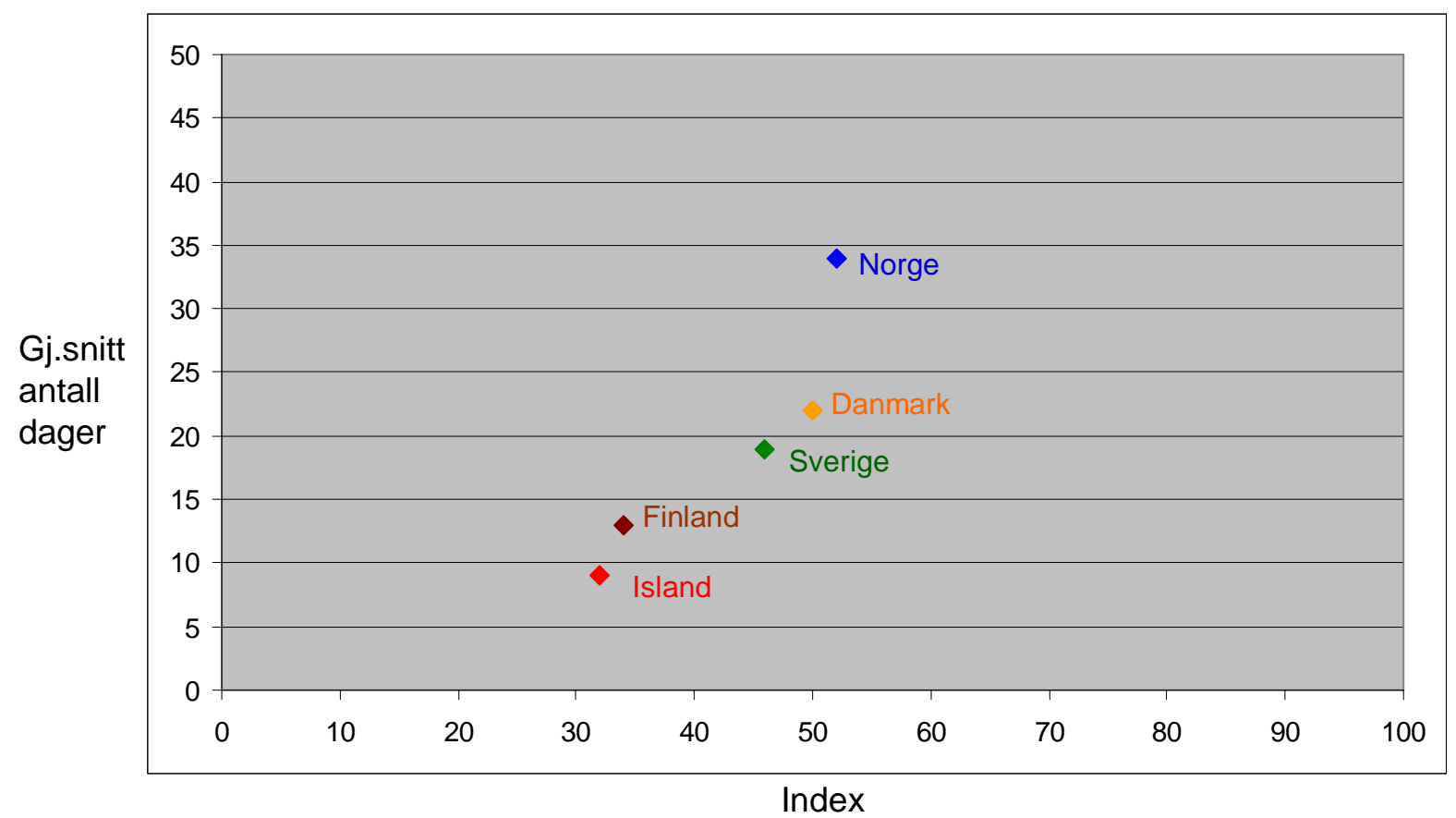


Det er akseptabelt å sykemelde seg når man føler ubehag pga. stress på arbeidet

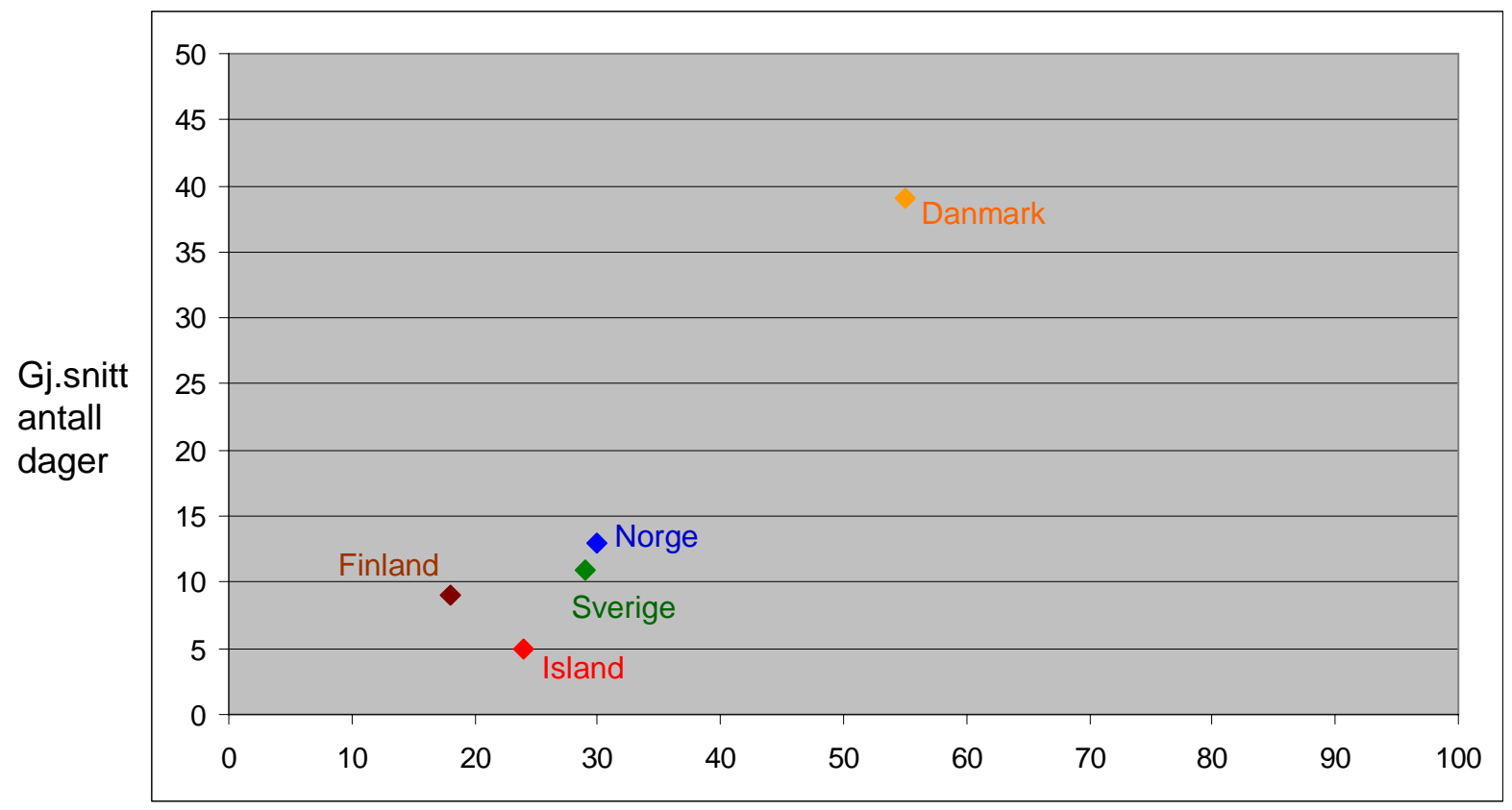

Index

Det er akseptabelt å sykemelde seg når man har nære familiemedlemmer som behøver ens støtte/omsorg

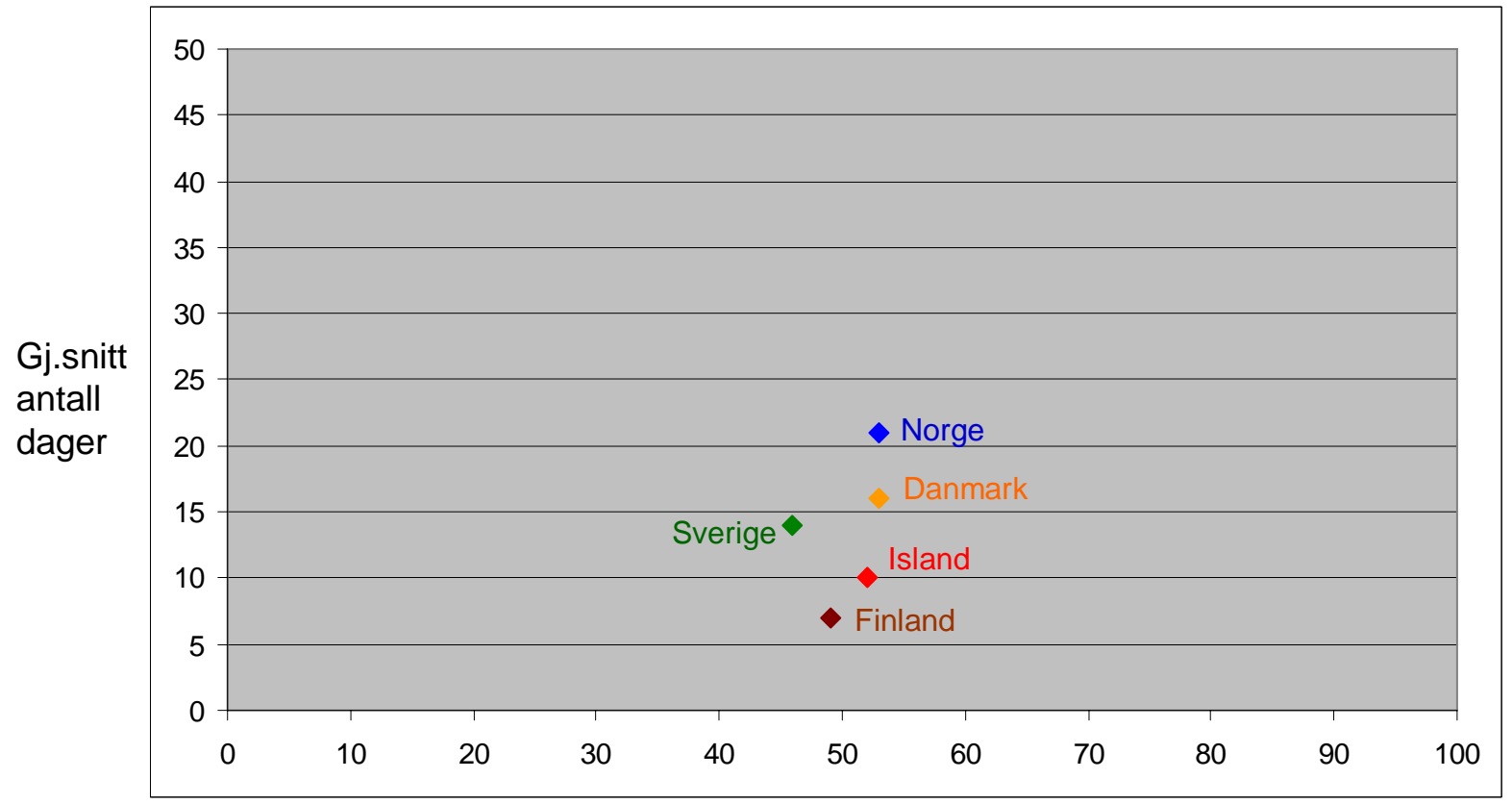

Index 


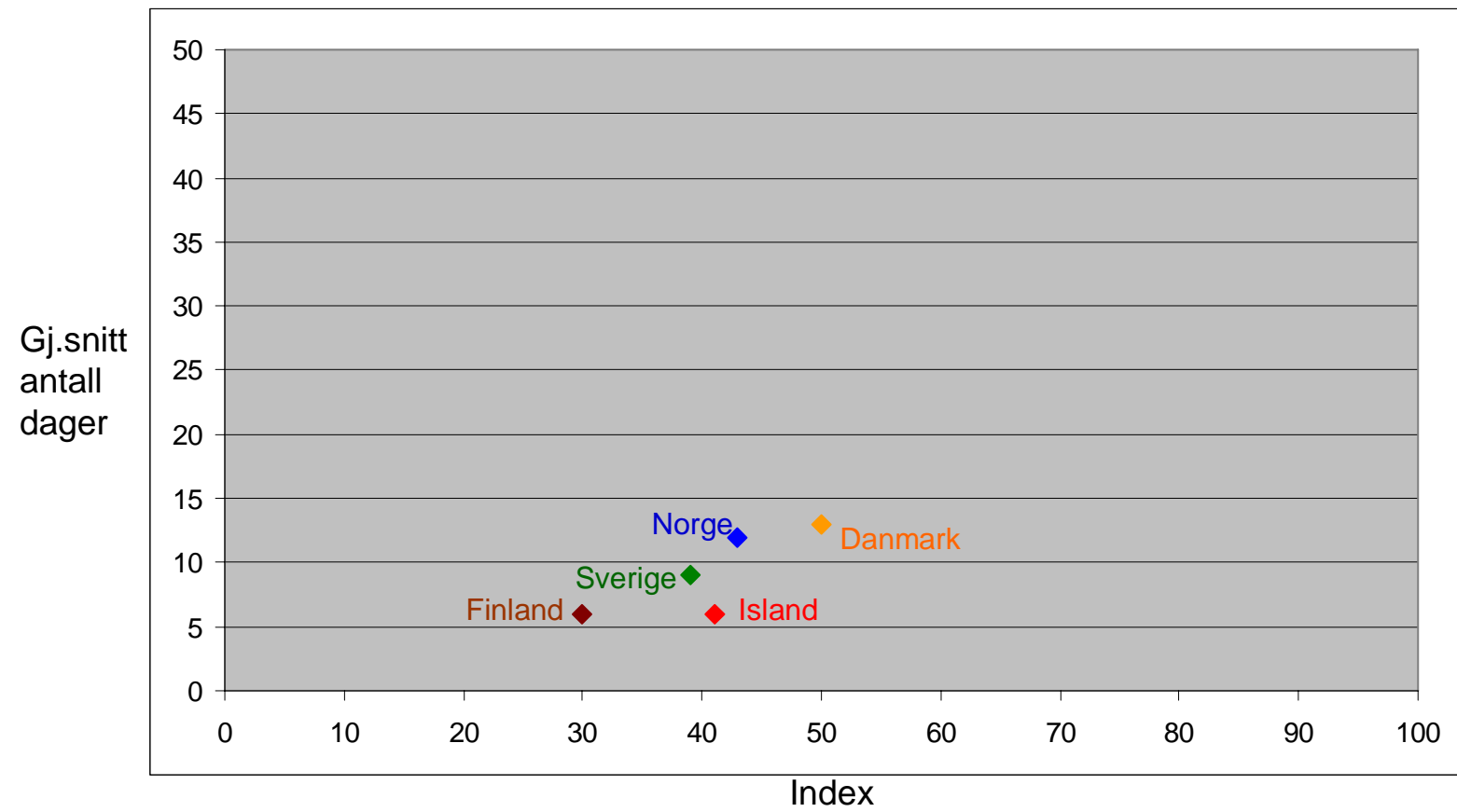

\section{Det er akseptabelt å sykemelde seg når man er misfornøyd med forhold på arbeidsplassen}

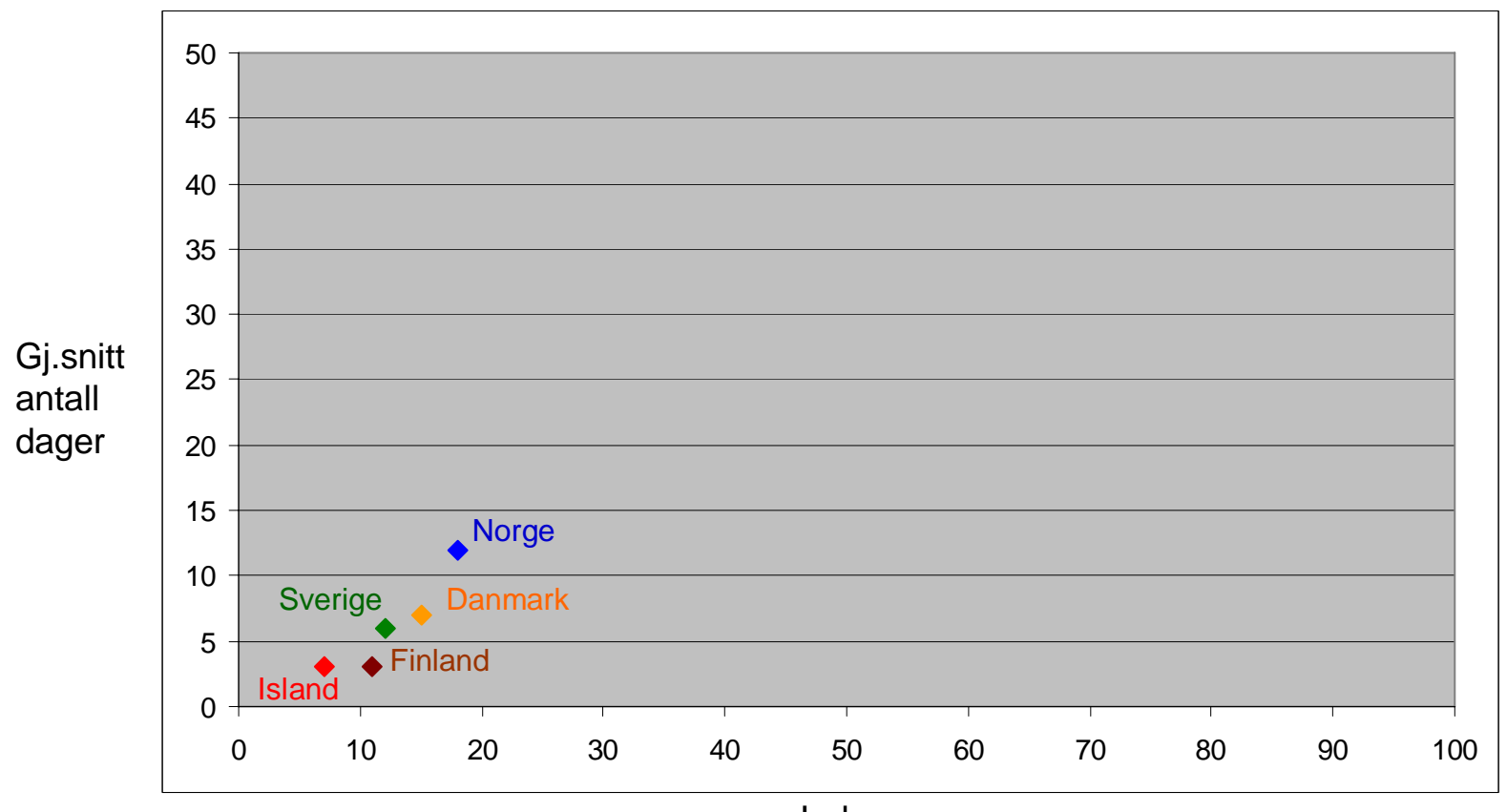

Index 
Det er akseptabelt å sykemelde seg når man har fått for lite søvn

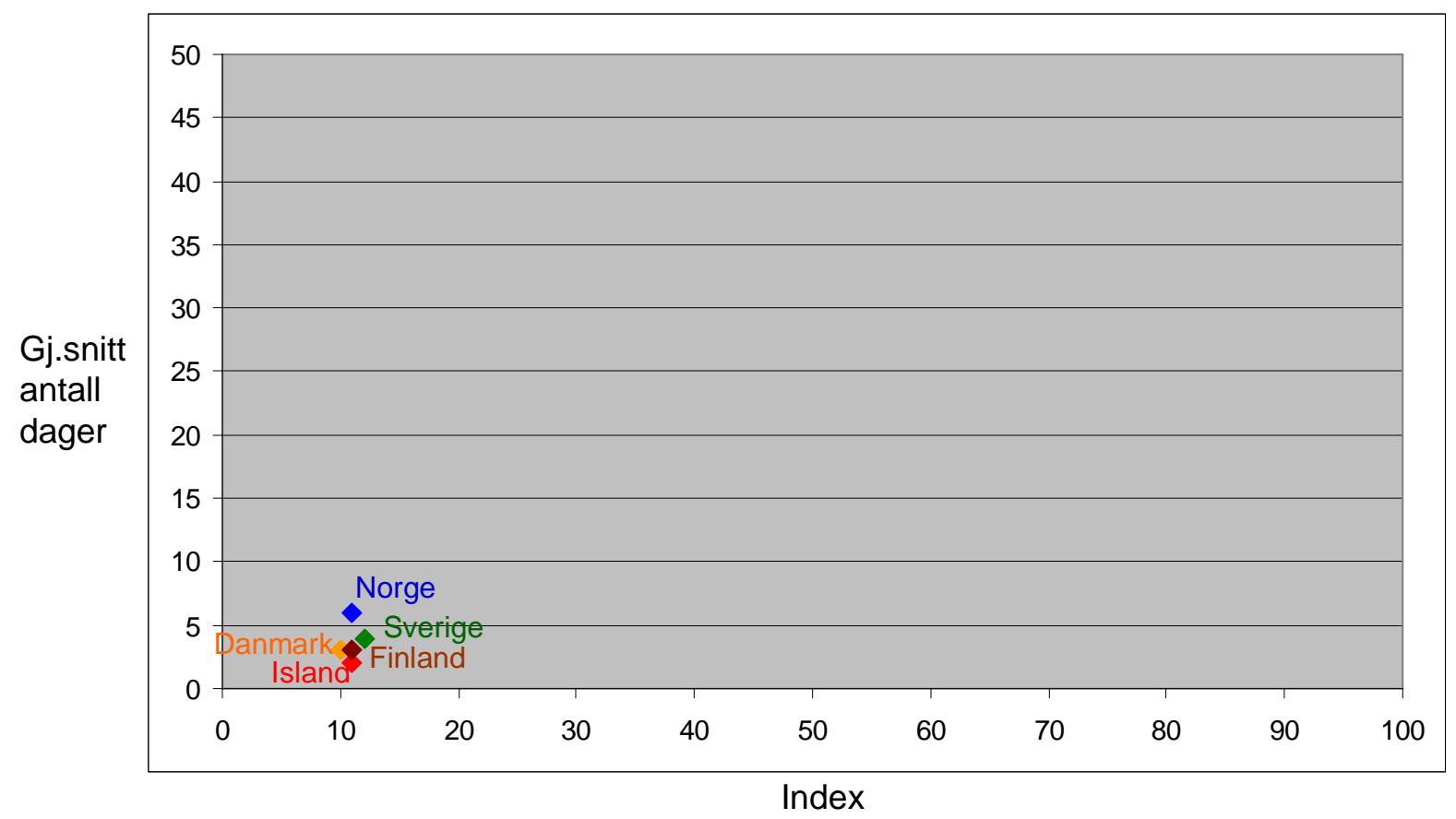




\section{Påstander om langtids sykefravær}

Arbeidstagerne i de fem nordiske landene skulle også ta stilling til tre ulike påstander knyttet til langtids sykefravær. De tre påstandene var:

Jeg synes det er mer akseptabelt å være sykemeldt hvis det er ansatt vikar i stillingen

Jeg synes det er mer akseptabelt å være sykemeldt når det offentlige dekker utgiftene til sykelønn

Jeg kunne tenke meg å arbeide helt eller delvis i en sykdomsperiode hvis arbeidsgiver tilrettelegger for meg.

\subsection{Påstander om langtids sykefravær - "Jeg syes det er} mer akseptabelt å være sykemeldt hvis det er ansatt vikar i stillingen"

Den første påstanden arbeidstagerne skulle ta stilling til var ”Jeg synes det er mer akseptabelt å være sykemeldt hvis det er ansatt vikar i stillingen”. Nedenfor presenteres forskjellene mellom de ulike landene når det gjelder det å være enig eller uenig i denne påstanden.

Påstand: Jeg synes det er mer akseptabelt å være sykemeldt hvis det er ansatt vikar i stillingen

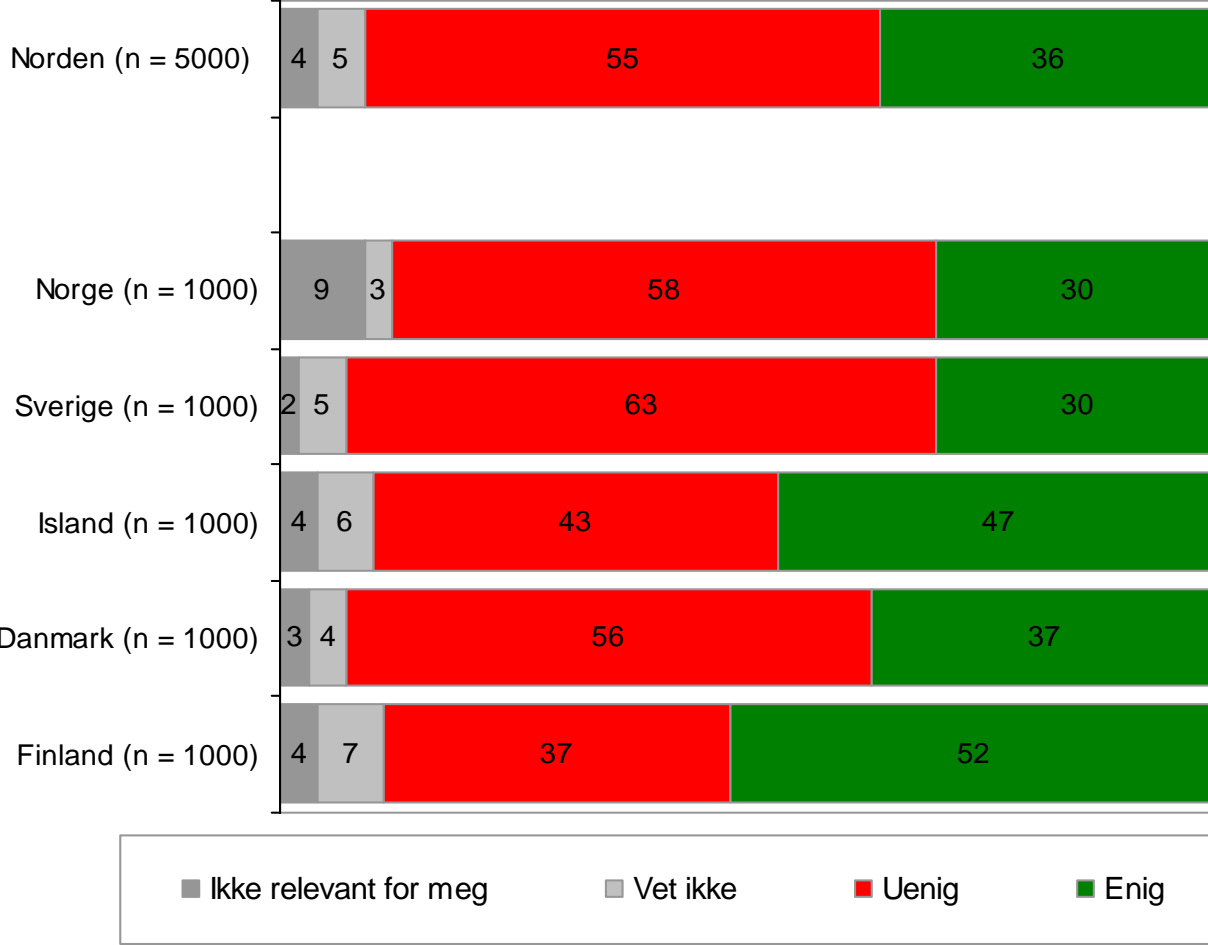


Kvinner er i større grad enige i påstanden enn menn, Norden sett under ett. $41 \%$ av kvinnene er enige i påstanden mot $31 \%$ blant mennene.

De som er under 30 år er i høyere grad enige i påstanden enn de som er eldre, Norden sett under ett. $46 \%$ av de unge er enige i påstanden om at det er mer akseptabelt å være sykemeldt hvis det er ansatt en vikar i stillingen, mot $35 \%$ blant de som er 30 år eller eldre.

Andelen som er enige i påstanden reduseres med økende utdanning. $40 \%$ av de med lavest utdanning er enige i påstanden, mot $34 \%$ av de med høyest utdanning.

De som arbeider i offentlig sektor er i høyere grad enn de som arbeider i privat sektor enige i påstanden om at det er mer akseptabelt å være sykemeldt hvis det er ansatt en vikar i stillingen. $40 \%$ av de som er ansatt i offentlig sektor er enige i påstanden, mot $34 \%$ av de som er ansatt i privat sektor. $36 \%$ av de som er selvstendig næringsdrivende er enige i påstanden.

Andelen som er enige i påstanden synker med størrelsen på bedriften arbeidstagerne arbeider i. $41 \%$ av de som arbeider i bedrifter med færre enn 15 ansatte er enige i at det er mer akseptabelt å være sykemeldt hvis det er ansatt en vikar i stillingen, mot 28 \% i bedrifter med 200 ansatte eller flere.

Andelen som er enige i påstanden er høyere blant de som arbeider få timer i uken enn blant de som arbeider mange timer i uken. $41 \%$ av de som arbeider 8-31 timer i uken er enige i at det er mer akseptabelt å være sykemeldt hvis det er ansatt en vikar i stillingen, mot $32 \%$ av de som arbeider 40 timer eller mer i uken.

Vi ser en del forskjeller mellom hvor enige ulike yrkesgrupper er i påstanden. De yrkesgruppene som i størst grad er enige i påstanden er de som arbeider innenfor undervisning inkl. barnehage (51 \% er enige), de som arbeider innen hotell/kafé/restaurant (47\% er enige) og de som jobber innen jordbruk/skogbruk/fiske (47 \% er enige). De yrkesgruppene som i minst grad er enige i påstanden er de som er ledere (27 \% er enige) og de som arbeider innenfor gruppen ingeniør/IT/telekommunikasjon (26 \% er enige). 


\subsection{Påstander om langtids sykefravær - ”Jeg syes det er mer akseptabelt å være sykemeldt når det offentlige dekker utgiftene til sykelønn”}

Den neste påstanden arbeidstagerne skulle ta stilling til var ”Jeg synes det er mer akseptabelt å være sykemeldt når det offentlige dekker utgiftene til sykelønn”. Nedenfor presenteres forskjellene mellom de ulike landene når det gjelder det å være enig eller uenig i denne påstanden.

Påstand: Jeg synes det er mer akseptabelt å være sykemeldt når det offentlige dekker utgiftene til sykelønn.

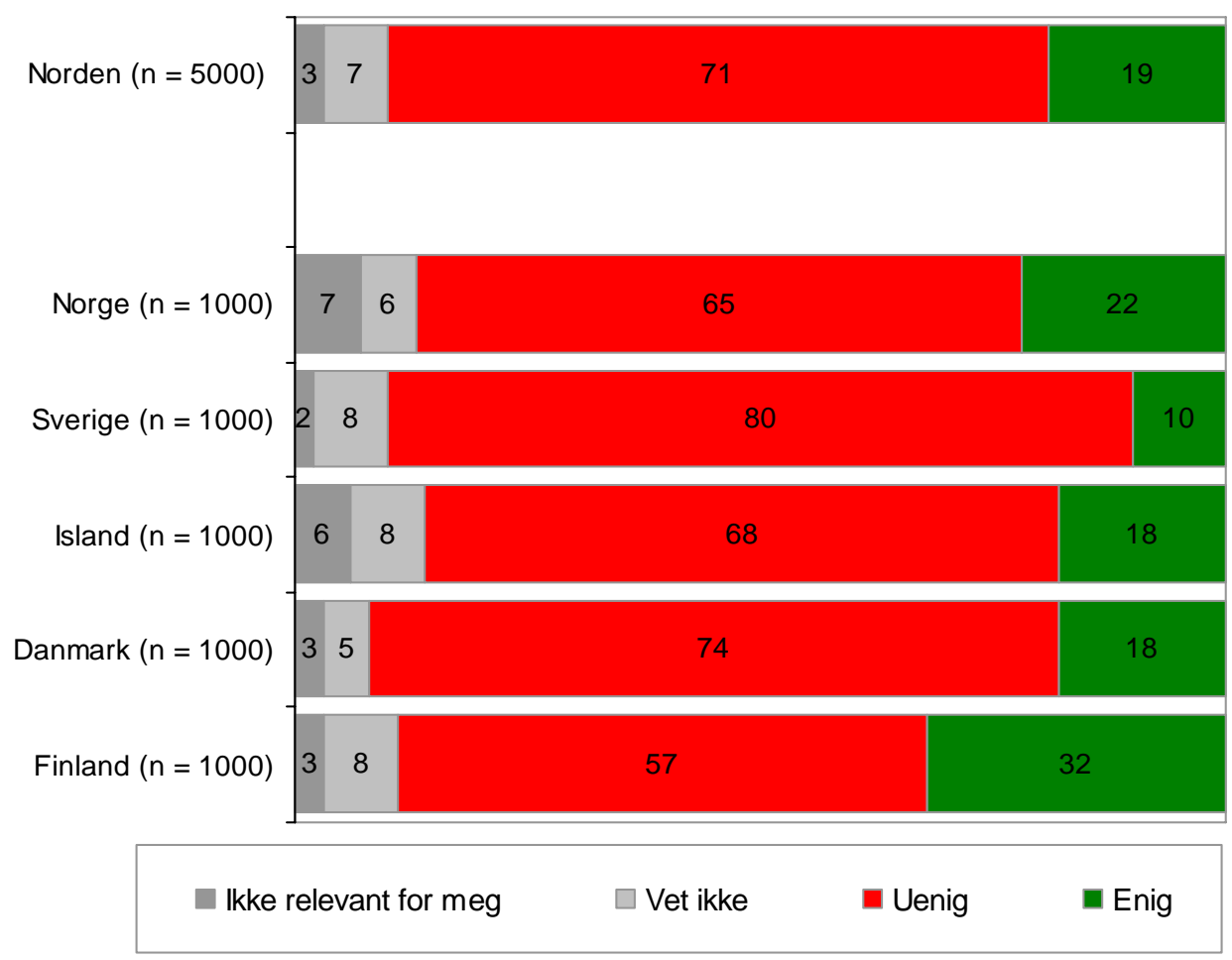

I Norden sett under ett er $19 \%$ av arbeidstagerne enige i påstanden, mens $71 \%$ er uenig. Vi ser imidlertid at det er en del forskjeller mellom de ulike landene. Arbeidstagerne i Finland og er de som i høyest grad sier de er enige i påstanden med $32 \%$. Arbeidstagerne i Sverige er i minst grad enig i påstanden med $10 \%$.

Kvinner er i større grad enige i påstanden enn det menn er, Norden sett under ett. $20 \%$ av kvinnene er enige i påstanden mot $17 \%$ blant mennene.

De som er under 30 år er i høyere grad enige i påstanden enn de som er eldre, Norden sett under ett. $22 \%$ av de unge er enige i påstanden om at det er mer akseptabelt å være sykemeldt hvis det offentlige dekker utgiftene til sykelønn, mot 17 - 19 \% blant de som er eldre. 
Andelen som er enige i påstanden reduseres med økende utdanning. $26 \%$ av de med lavest utdanning er enige i påstanden, mot $15 \%$ av de med høyest utdanning.

De som arbeider i privat sektor og de som arbeider i offentlig sektor er i like stor grad enige i påstanden. Selvstendig næringsdrivende skiller seg heller ikke ut fra de to gruppene.

Andelen som er enige i påstanden synker med størrelsen på bedriften arbeidstagerne arbeider i. $23 \%$ av de som arbeider i bedrifter med færre enn 15 ansatte er enige i at det er mer akseptabelt å være sykemeldt når det offentlige dekker utgiftene, mot $13 \%$ i bedrifter med 200 ansatte eller flere.

Andelen som er enige i påstanden er høyere blant de som arbeider få timer i uken enn blant de som arbeider mange timer i uken. $24 \%$ av de som arbeider 8-31 timer i uken er enige i at det er mer akseptabelt å være sykemeldt om det offentlige dekker utgiftene til sykelønn, mot $14 \%$ av de som arbeider 40 timer eller mer i uken.

Vi ser en del forskjeller mellom hvor enige ulike yrkesgrupper er i påstanden. De yrkesgruppene som i størst grad er enige i påstanden er de som arbeider innen hotell/kafé/restaurant (27\% er enige) og de som jobber innen jordbruk/skogbruk/fiske (28 \% er enige). De yrkesgruppene som i minst grad er enige i påstanden er de som er ledere (14 \% er enige) de som arbeider innenfor gruppen ingeniør/IT/telekommunikasjon (12\% er enige) og de som jobber som megler/konsulent/rådgiver (13\% er enige). 


\subsection{Påstander om langtids sykefravær - ”Jeg kunne tenke meg å arbeide helt eller delvis i en sykdomsperiode hvis arbeidsgiver tilrettelegger for meg”}

Den tredje og siste påstanden arbeidstagerne skulle ta stilling til var "Jeg kunne tenke meg å arbeide helt eller delvis i en sykdomsperiode hvis arbeidsgiver tilrettelegger for meg”. Nedenfor presenteres forskjellene mellom de ulike landene når det gjelder det å være enig eller uenig i denne påstanden.

Påstand: Jeg kunne tenke mig å arbeide helt eller delvis i en sykdomsperiode hvis arbeidsgiver tilrettelegger for meg.

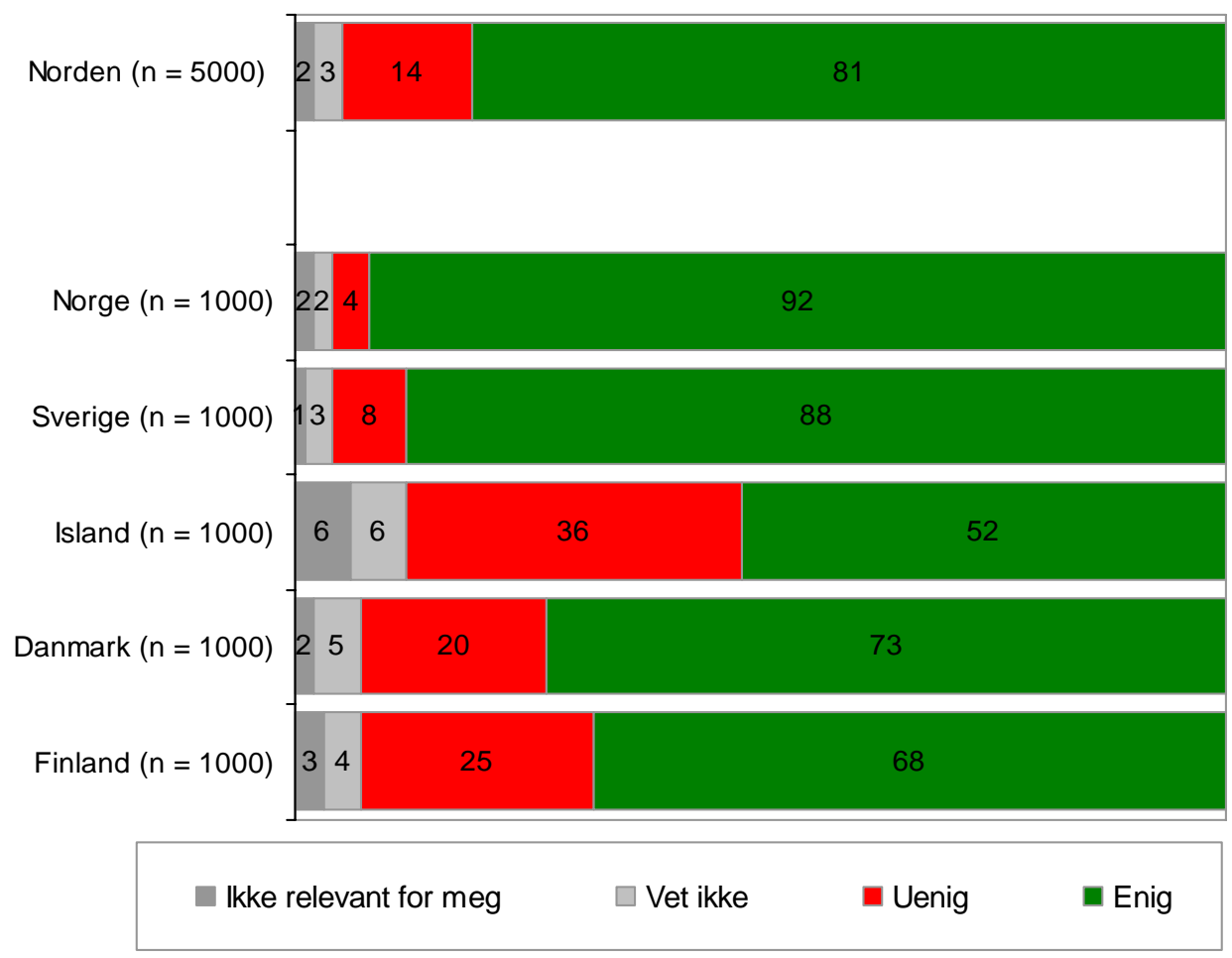

I Norden sett under ett er $81 \%$ av arbeidstagerne enige i påstanden, mens $14 \%$ er uenig. Vi ser imidlertid også her at det er forskjeller mellom de ulike landene. Arbeidstagerne i Norge og i Sverige er de som i høyest grad sier de er enige i påstanden med henholdsvis $92 \%$ og 88 \%. Arbeidstagerne på Island er i minst grad enig i påstanden med $52 \%$.

Kvinner er i noe større grad enige i påstanden enn menn, Norden sett under ett. $83 \%$ av kvinnene er enige i påstanden mot $79 \%$ blant mennene.

De som er 50 - 65 år gamle er i mindre grad enige i påstanden enn de som er yngre, Norden sett under ett. 78 \% av de eldste er enige i påstanden om at de kunne tenke seg å arbeide helt eller delvis i en sykdomsperiode hvis arbeidsgiver tilretterlegger arbeidet for dem, mot $81 \%-83 \%$ blant de som er yngre. 
Andelen som er enige i påstanden øker med økende utdanning. 72 \% av de med lavest utdanning er enige i påstanden, mot $84 \%$ av de med høyest utdanning.

De som arbeider i offentlig sektor er i noe høyere grad enn de som arbeider i privat sektor enige i påstanden om at de kunne tenke seg å arbeide helt eller delvis i en sykdomsperiode hvis arbeidsgiver tilrettelegger arbeidet for dem. $82 \%$ av de som er ansatt i offentlig sektor er enige i påstanden, mot $80 \%$ av de som er ansatt i privat sektor.

De som arbeider i bedrifter med 200 ansatte eller flere er i større grad enige i påstanden om at de kunne tenke seg å arbeide helt eller delvis i en sykdomsperiode hvis arbeidsgiver tilrettelegger arbeidet for dem enn de som arbeider i mindre bedrifter, Norden sett under ett. $84 \%$ av de som arbeider i de største bedriftene er enige i påstanden, mot $80 \%-81 \%$ blant de som arbeider i mindre bedrifter.

Det er ingen systematiske forskjeller i hvor enige man er i påstanden ut fra hvor mange timer i uken man arbeider.

Vi ser en del forskjeller mellom hvor enige ulike yrkesgrupper er i påstanden. De yrkesgruppene som i størst grad er enige i påstanden er de som arbeider innenfor gruppen ingeniører/IT/telekommunikasjon (87 \% er enige), de som arbeider som ledere (86 \% er enige) og de som arbeider som megler/konsulent/rådgiver (86 \% er enige). De yrkesgruppene som i minst grad er enige i påstanden er de som arbeider $\mathrm{i}$ andre serviceyrker herunder reiseliv (73\% er enige), industriarbeidere ( $74 \%$ er enige) og de som arbeider innenfor jordbruk/skogbruk/fiske (70 \% er enige). 


\section{Vedlegg - spørreskjema}

Hei, jeg ringer fra [...]. Vi holder for tiden på med en undersøkelse for Nordisk Ministerråd om sykefravær og ønsker i den forbindelse å stillen noen spørsmål til en i husstanden som er mellom 18 og 65 år og som gjennomsnittlig arbeider minimum 8 timer i uken. Spørsmålene vil ta ca. 5 minutter.

De som gjennomsnittlig arbeider mindre enn 8 timer i uken skal ikke intervjues.

Spørsmål 0.

ALLE

Omtrent hvor mange timer arbeider du i gjennomsnitt per uke?
8-15 timer
16-23 timer
24-31 timer
32-39 timer
40-49 timer
50 timer eller mer

Spørsmål 1.

ALLE

Jeg skal nå lese opp noen årsaker man kan ha for å sykemelde seg, og ønsker at du skal oppgi om du synes den enkelte årsaken jeg leser opp er akseptabel eller ikke.

Jeg ønsker at du svarer langs en skala fra 1 til 10 der 1 betyr aldri akseptabelt og 10 betyr alltid akseptabelt.

Det er akseptabelt å sykemelde seg når man...

RANDOMISERE

A. Er forkjølet med litt feber

B. Føler seg dårlig etter å ha drukket mye alkohol kvelden før

C. Har problemer med å komme seg på jobb på grunn av kortvarig manglende tilbud i barnehage, skole eller offentlig transport

D. Har fått for lite søvn

E. Har vanskeligheter i forbindelse med samlivsbrudd

F. Har nære familiemedlemmer som behøver ens støtte/omsorg

G. Er misfornøyd med forhold på arbeidsplassen

H. Føler ubehag på grunn av stress på arbeidet

I. Blir mobbet på arbeidsplassen 
1. Aldri akseptabelt

2.

3.

4.

5.

6.

7.

8.

9.

10. Alltid akseptabelt

11. Vet ikke (ikke les opp)

Spørsmål 2.

HVIS SVART ALTERNATIV 2 - 10 I SPØRSMÅL 1D

Hvis man sykemelder seg fordi man har fătt for lite søvn, hvor lenge kan dette (etter din mening) godtas?

LES OPP

1. 1 - 2 dager

2. Opptil 1 uke

3. Opptil 4 uker

4. Opptil 12 uker

5. Opptil 6 måneder eller mer

6. Kan ikke godtas (ikke les opp)

7. Vet ikke (ikke les opp)

Spørsmål 3.

HVIS SVART ALTERNATIV 2 - 10 I SPØRSMÅL 1E

Hvis man sykemelder seg fordi man har vanskeligheter i forbindelse med samlivsbrudd, hvor lenge kan dette (etter din mening) godtas?

LES OPP

1. $1-2$ dager

2. Opptil 1 uke

3. Opptil 4 uker

4. Opptil 12 uker

5. Opptil 6 måneder eller mer

6. Kan ikke godtas (ikke les opp)

7. Vet ikke (ikke les opp) 
Spørsmål 4.

\section{HVIS SVART ALTERNATIV 2 - 10 I SPØRSMÅL 1F}

Hvis man sykemelder seg fordi man har nære familiemedlemmer med problemer som behøver ens støtte/omsorg, hvor lenge kan dette (etter din mening) godtas?

LES OPP

1. $1-2$ dager

2. Opptil 1 uke

3. Opptil 4 uker

4. Opptil 12 uker

5. Opptil 6 måneder eller mer

6. Kan ikke godtas (ikke les opp)

7. Vet ikke (ikke les opp)

Spørsmål 5.

HVIS SVART ALTERNATIV 2 - 10 I SPØRSMÅL 1G

Hvis man sykemelder seg fordi man er misfornøyd med forhold på arbeidsplassen, hvor lenge kan dette (etter din mening) godtas?

LES OPP

1. $1-2$ dager

2. Opptil 1 uke

3. Opptil 4 uker

4. Opptil 12 uker

5. Opptil 6 måneder eller mer

6. Kan ikke godtas (ikke les opp)

7. Vet ikke (ikke les opp)

Spørsmål 6.

HVIS SVART ALTERNATIV 2 - 10 I SPØRSMÅL 1H

Hvis man sykemelder seg fordi man føler ubehag på grunn av stress på arbeidet, hvor lenge kan dette (etter din mening) godtas?

LES OPP

1. $1-2$ dager

2. Opptil 1 uke

3. Opptil 4 uker

4. Opptil 12 uker

5. Opptil 6 måneder eller mer

6. Kan ikke godtas (ikke les opp)

7. Vet ikke (ikke les opp) 
Spørsmål 7.

HVIS SVART ALTERNATIV 2 - 10 I SPØRSMÅL 1D

Hvis man sykemelder seg fordi man blir mobbet på arbeidsplassen, hvor lenge kan dette (etter din mening) godtas?

LES OPP

1. $1-2$ dager

2. Opptil 1 uke

3. Opptil 4 uker

4. Opptil 12 uker

5. Opptil 6 måneder eller mer

6. Kan ikke godtas (ikke les opp)

7. Vet ikke (ikke les opp)

Spørsmål 8.

ALLE

Så skal jeg komme med noen påstander om langtids sykefravær og ønsker at du oppgir om du er uenig eller enig med den enkelte påstanden. Om du ikke har noen mening eller problemstillingen i påstanden ikke er relevant for deg oppgir du det.

RANDOMISERE PÅSTANDER

Jeg synes det er mer akseptabelt å være sykmeldt hvis det er ansatt en vikar i stillingen

Jeg synes det er mer akseptabelt å være sykmeldt når det offentlige dekker utgiftene til sykelønn

Jeg kunne tenke meg å arbeide helt eller delvis i en sykdomsperiode hvis arbeidsgiver tilrettelegger arbeidet for meg
Uenig
Enig
Vet ikke
Ikke relevant for meg

Spørsmål 9.

ALLE

Noter kjønn

Kvinne

Mann

Spørsmål 10.

ALLE 
Hva er din alder?

Åpent - notere

Spørsmål 11.

ALLE

Hva er din høyeste fullførte utdanning?

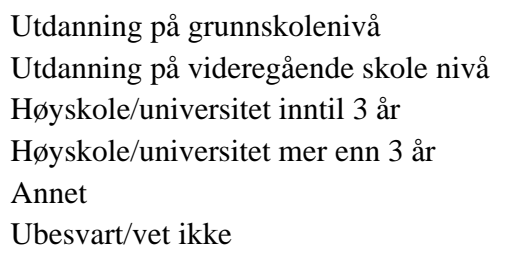

Spørsmål 12.

ALLE

Hva er ditt yrke? (Hvis respondenten har flere arbeidsforhold skal han/hun svare ut fra det arbeidsforholdet han/hun arbeider mest)

1. Leder

2. Kontorarbeid, inkl. regnskap, økonom

3. Megler, konsulent, rådgiver etc.

4. Ingeniør, it, telekommunikasjon

5. Helse, pleie, omsorg

6. Undervisning, inkl. barnehage

7. Butikk- og salgsarbeid

8. Hotell, kafé, restaurant etc.

9. Andre serviceyrker, herunder reiseliv

10. Presse, media, PR

11. Transport

12. Bygg og anlegg

13. Industriarbeid

14. Andre håndverksyrker

15. Jordbruk, skogbruk, fiske

16. Annet

17. Ubesvart/vet ikke

Spørsmål 13.

HVIS SVART ALTERNATIV 1 - 16 I SPØRSMÅL 12

Arbeider du i privat eller offentlig sektor? Eller er du selvstendig næringsdrivende? (Hvis respondenten har flere arbeidsforhold skal han/hun svare ut fra det arbeidsforholdet han/hun arbeider mest) 
1. Privat sektor

2. Offentlig sektor

3. Selvstendig næringsdrivende

4. Ubesvart/vet ikke

Spørsmål 14.

ALLE

Omtrent hvor mange ansatte er det i bedriften der du arbeider, inkludert deg selv? (Hvis respondenten har flere arbeidsforhold skal han/hun svare ut fra det arbeidsforholdet han/hun arbeider mest)

1. 1 , meg selv

2. $2-4$

3. $5-9$

4. $10-14$

5. $15-19$

6. $20-29$

7. $30-49$

8. $50-99$

9. $100-199$

10. $200-499$

11. 500 eller flere

12. Ubesvart/vet ikke

Spørsmål 15.

ALLE

I hvilket fylke bor du i?

Skriv inn/registrer

Da har jeg ikke flere spørsmål. Takk for hjelpen! 